NBER WORKING PAPER SERIES

THE GLOBALIZATION OF TRADE AND DEMOCRACY, 1870-2000

J. Ernesto López-Córdova

Christopher M. Meissner

Working Paper 11117

http://www.nber.org/papers/w11117

NATIONAL BUREAU OF ECONOMIC RESEARCH

1050 Massachusetts Avenue

Cambridge, MA 02138

February 2005

The views expressed herein are those of the author(s) and do not necessarily reflect the views of the National Bureau of Economic Research.

(C) 2005 by J. Ernesto Lopez-Cordova and Christopher M. Meissner. All rights reserved. Short sections of text, not to exceed two paragraphs, may be quoted without explicit permission provided that full credit, including (C) notice, is given to the source. 
The Globalization of Trade and Democracy, 1870-2000

J. Ernesto López-Córdova and Christopher M. Meissner

NBER Working Paper No. 11117

February 2005

JEL No. F1, N0

\begin{abstract}
We study whether international trade fosters democracy. The likely endogeneity between democracy and trade is addressed via the gravity model of trade, allowing us to obtain a measure of natural openness. This serves as our instrumental variable for actual trade openness à la Frankel and Romer (1999). We use this powerful instrument to obtain estimates of the causal impact of openness on democratization. A positive impact of openness on democracy is apparent from about 1895 onwards. Late nineteenth century trade globalization may have helped generate the "first wave" of democratization. Between 1920 and 1938 countries more exposed to international trade were less likely to become authoritarian. Finally, our post-World War II results suggest that a one standard deviation increase in trade with other countries could bring countries like Indonesia, Russia or Venezuela to be as democratic as the US, Great Britain or France. We also see some variation in the impact of openness by region and note that commodity exporters and petroleum producers do not seem to become more democratic by exporting more of such items.
\end{abstract}

\author{
J. Ernesto López-Córdova \\ Inter-American Development Bank \\ INT/ITD Stop W608 \\ 1300 New York Ave, NW \\ Washington, DC 20577 \\ joselc@iadb.org \\ Christopher M. Meissner \\ Faculty of Economics \\ University of Cambridge \\ Austin Robinson Building \\ Sidgwick Avenue \\ Cambridge CB3 9DD \\ UK \\ and NBER \\ chris.meissner@econ.cam.ac.uk
}




\title{
The Globalization of Trade and Democracy, 1870-2000
}

\author{
J. Ernesto López-Córdova and Christopher M. Meissner* \\ Working version. Comments welcome. \\ This version: February 1, 2005
}

\begin{abstract}
We study whether international trade fosters democracy. The likely endogeneity between democracy and trade is addressed via the gravity model of trade, allowing us to obtain a measure of natural openness. This serves as our instrumental variable for actual trade openness à la Frankel and Romer (1999). We use this powerful instrument to obtain estimates of the causal impact of openness on democratization. A positive impact of openness on democracy is apparent from about 1895 onwards. Late nineteenth century trade globalization may have helped generate the "first wave" of democratization. Between 1920 and 1938 countries more exposed to international trade were less likely to become authoritarian. Finally, our post-World War II results suggest that a one standard deviation increase in trade with other countries could bring countries like Indonesia, Russia or Venezuela to be as democratic as the US, Great Britain or France. We also see some variation in the impact of openness by region and note that commodity exporters and petroleum producers do not seem to become more democratic by exporting more of such items.
\end{abstract}

\section{Introduction}

Does democracy go hand in hand with international trade? Or, on the contrary, does trade integration stem incipient democracy? The questions go beyond mere academic interest. From an economist's perspective, answering those questions is relevant on at least three grounds. First, as argued by Amartya Sen (1999), a democratic political system is central to the process of development and is essential for understanding and fulfilling economic needs. Other authors have shown that democracy can have a positive impact on economic growth, on reducing economic

*López-Córdova: Inter-American Development Bank, INT/ITD Stop W608, 1300 New York Ave. NW, Washington, DC 20577, USA (email: joselc@iadb.org); Meissner: Faculty of Economics, University of Cambridge, Austin Robinson Building, Sidgwick Avenue, Cambridge CB3 9DD, England (email: chris.meissner@econ.cam.ac.uk) and NBER. We thank seminar and conference participants at Boston University, Cambridge, Dartmouth, the Fifth World Congress of Cliometrics, Humboldt University, NBER Summer Institute 2004, Pompeu Fabra, and UC Berkeley for comments. Gernot Doppelhofer, Hashem Pesaran, Alexandra Olmedo, and Jeff Williamson also kindly provided considerable interest and feedback in the initial stages. Rafael de Hoyos provided able research assitance and discussion. The opinions expressed herein are those of the authors and do not necessarily reflect the views of the IDB or its member countries. 
volatility, on the ability to handle adverse shocks, and on achieving an equitable distribution of income and assets. ${ }^{1}$ Promoting closer economic integration in the world might also help achieve economic development by strengthening efforts toward building better institutions. Second, the common perception among policy makers that there exists a positive causal link between trade openness and democratic governance has been an important rationale for deepening trade liberalization, both at the global and regional levels. ${ }^{2}$ Therefore, to the extent that trade fosters democracy, if at all, the implications are crucial for global trade talks and for the negotiation of regional integration arrangements. Third, from a long-run perspective, there may be a case that today's most economically advanced democracies achieved such status partially because of their engagement with international trade.

As we discuss in section 2, the theoretical debate on the link between the globalization of trade and democracy is far from settled. However appealing arguments on either camp might be, they remain to be substantiated by a careful evaluation of the historical record. Since the interplay between world trade and democracy has important implications for economic welfare, for the conduct of commercial policy and for the shape that global economic integration takes in the future, in this paper we investigate whether there is any systematic evidence suggesting that trade globalization could be responsible for the growing preponderance of democracy. We look at three time periods spanning 130 years of world history: the first era of globalization, immediately preceding World War I (1870 to 1910); the inter-war years (1917-1939), which saw a collapse in international trade; and the post-World War II period (1960-2000), which toward the end has witnessed a second era of globalization. We analyze whether trade openness what we sometimes call globalization for short - causally explains democracy. We define the latter not simply as a political system in which the chief executive is chosen through free, fair, and competitive elections, but in which there also exist institutional constraints on the power granted to the executive and in which political participation and the respect of civil liberties is guaranteed.

Figures 1, 2, and 3 show the evolution of the global average value of "openness" to trade and the average of our preferred measure of democracy for the three historical periods we 
consider in this paper. The figures suggest that, over the long run, there seems to be a positive relationship between trade and democracy. To date, there has been relatively little quantitative empirical research on the relationship after 1950, and there is no research that we are aware of for the years prior to 1950. Moreover, in the literature that studies the post-World War II period, there is no consensus on whether the apparent positive link holds under a more careful empirical analysis. Margit Bussmann (2001) explores the issue using simultaneous equation techniques and instrumental variables (different from those we propose) and finds that there is little evidence that trade openness is associated with democracy in the late twentieth century. Quan Li and Rafael Reuveny (2002) report a negative relationship between trade openness and democracy after 1970, but do not consider a number of important econometric specification problems. More recently, in a broader study looking at the interplay between democracy, rule of law, openness, and growth, Roberto Rigobón and Rodrik (2004) find an inverse relationship between trade openness and democracy. Our view, spelled out in the next section, is that the existing empirical studies suffer from potentially misleading shortcomings that call for continued research on the issue.

We contribute to the scant empirical literature by refining the methodological approach to the problem, by providing a long-term historical perspective on the issue, and by presenting some initial thoughts on the channels through which globalization may affect democracy. In particular, we propose a new, powerful instrumental variable to better sort out the causal impact of trade on democracy. Our instrument uses exogenous geographic information to predict trade flows similar to Jeffrey A. Frankel and David Romer (1999). We use this in two-stage least squares regressions for data from the period 1870 to 2000. Contrary to the empirical work we are familiar with, we find some evidence of a substantive and statistically significant positive impact of openness on the level of democracy. Most of our evidence relies on cross-sectional variation in the data to identify the relationship of interest and our conclusion that there is a positive relationship hinges crucially on this. We believe our instrument, which measures proximity to other nations in a complex way, gives us a good impression of the reduced form association between trade openness and democracy. But there is some evidence that other 
time-invariant national characteristics which are correlated with proximity are creating more democracy. However, since it is not immediately apparent which factors these are and our instrument seems to incorporate truly exogenous information that is nonetheless time invariant, we conclude that there is more evidence for a positive relationship than otherwise.

In what follows, we begin by reviewing some theoretical arguments of why we might expect to find a positive link between trade openness and democracy, as well as the existing empirical literature on the subject. We outline our research design in Section 3 and present our econometric results in Section 4. We conclude by putting these in greater context while also suggesting further lines of investigation.

\section{Trade and democracy: Theory and empirical evidence}

The view, both in academic and popular discourse, that globalization helps build democracy typically rests on two arguments: (i) that globalization is conducive to economic development and (ii) that economic development fosters democracy. The first argument is the subject of a fierce academic debate in economics. Frankel and Romer (1999) and Francisco Alcalá and Antonio Ciccone (2004), among others, argue that trade openness is causally correlated with economic growth. Francisco Rodríguez and Rodrik (1999) offered an (early) skeptical assessment of that literature. Moreover, Rodrik, Arvind Subramanian and Francesco Trebbi (2002) underscore the importance of institutions as the main driver of economic prosperity and find that trade has an insignificant impact on growth and often appears to have a negative effect. ${ }^{3}$ Regarding the second argument, the proposition that economic development fosters democracy has been advanced by Seymour Martin Lipset (1959). Barro (1999) and, more recently, Carles Boix and Susan C. Stokes (2002) find econometric evidence in support of Lipset's proposition.

According to Jagdish Bhagwati (2004), Lipset's views have usually been interpreted as implying that economic development is accompanied by the emergence of a middle class demanding expanded political rights, eventually giving rise to democracy. In accordance with this view, Justin Yifu Lin and Jeffrey B. Nugent (1995, p. 2336) state that

“...a dictatorship or authoritarian regime may not be compatible with long- 
run economic growth. The more successful is such a state in achieving economic development, the more likely it is that the state will face a legitimacy crisis. This is because both a financially independent middle class and the integration of the domestic economy with the world economy are at the same time both necessary conditions for and natural effects of economic success in the modern world. As a result, democratic ideology of DCs [developed countries] may penetrate the middle class and undermine the legitimacy of the regime. These pressures may also force the state to cut its own power of intervention in order to make credible its commitment to such reforms. Thus, authoritarian states may gradually be transformed into democratic states, as seems to be happening in Korea, Taiwan, and Chile."

The preeminence given to the emergence of a middle class is reminiscent of recent work by Acemoglu and Robinson (2001) which puts the distribution of income and assets at the center of a model of political transitions. When the distribution of assets is skewed, economic elites fear the adoption of redistributive policies by a democratic government and, as consequence, support authoritarian regimes. In this view, egalitarian societies are more likely to be democratic as there would be less propensity and opposition to redistribution. Acemoglu and Robinson (2001) suggest that policies that result in a better distribution of assets, such as improved access to education by the poor, to the extent that they ameliorate the appeal of redistribution, would prop efforts to democratize. Extending this line of argument, Acemoglu and Robinson (2003) argue that globalization should improve income distribution - through Stolper-Samuelson effects for example - and, in turn, should reduce political conflict and favor democratization.

The evidence on whether globalization results in a better distribution of income is mixed. On the one hand, there is ample evidence suggesting that trade openness and FDI flows may worsen wage disparities. ${ }^{4}$ That would occur for example if the demand for skilled workers in less-developed countries rises as foreign producers bring with them advanced technologies or as exporters attempt to upgrade their products to access foreign markets. Acemoglu and Robinson (2003) present a model in which even when the gap between skilled and unskilled 
wages deepens, democracy may ensue, arguing that one could think of skilled workers as representing the middle class. On the other hand, focusing on income distribution in general, and not simply on wage disparities, recent studies come to a more benign assessment of how trade openness affects inequality. Computable-general equilibrium modelling of how trade liberalization affects product and factor prices, coupled with household level information, suggests that trade liberalization within Mercosur in Argentina [Guido G. Porto (2003)] or that continued tariff elimination in Mexico [Elena Ianchovichina, Alessandro Nicita, and Isidro Soloaga (2001)] improve income distribution. Other studies indicate that regions within China and Mexico that are more globalized have more equal income distribution [Shang-Jin Wei and Yi Wu (2002); Fernando Borraz and Ernesto López-Córdova (2004)].

There is of course an extensive non-empirical literature in political science that offers alternative explanations and theoretical predictions of how globalization affects democracy. Li and Reuveny (2003) provide an extensive survey, pointing that authors reach opposite conclusions on the subject. A review of that literature is beyond the scope of the present paper. We will simply note in passing that several of the purported reasons why globalization would affect the level of democracy are difficult, if not impossible, to operationalize in an econometric exercise - e.g., the argument that globalization "degrades the concept of citizenship" or that "it deepens ethnic and class cleavages and diminishes the national-cultural basis of democracy". ${ }^{5}$

In sum, theoretical arguments in the economics and political science disciplines do not come to an unambiguous prediction about how globalization affects democracy. Moreover, however persuasive economic models on the subject appear to be, empirical evidence in support of each of the building blocs in those models is inconclusive. Therefore, asking whether democracy goes hand in hand with globalization is, ultimately, an empirical question.

To the best of our knowledge, the only papers that set out to analyze whether trade openness causally explains the level of democracy, in addition to ours, are those by Li and Reuveny (2003), Bussmann (2001), and Rigobón and Rodrik (2004). Like our paper, both use the same source for defining democracy (see Section 3.2), although Rigobón and Rodrik (2004) use a slightly different definition. Contrary to our paper, all three sets of authors focus only on the post- 
World War II period. The main issue that authors must deal with in analyzing the causal link between globalization and democracy is the endogenous relationship between the two variables, and the three papers main difference lies in this crucial aspect.

Li and Reuveny (2003) estimate pooled OLS regressions that measure the degree of globalization in terms of openness to trade, FDI, and portfolio capital flows, as well as on the number of democracies in the region to which a country belongs, in order to capture the diffusion of democratic ideas across borders. In addition, they include lagged values of democracy as a regressor, as well as information on inflation, and income per capita (in logarithms) and its growth rate. Endogeneity is dealt with by including lagged values of the globalization variables. The authors find a negative relationship between trade openness and democracy. However, in our view, there are several problems with the econometric specification used by the authors. First, if there is serial correlation in the error terms of the regression, as is likely, including lags of the globalization variables does not solve the endogeneity problem. Second, with serial correlation, lagged democracy would be correlated with the error term and ordinary least squares yields biased coefficient estimates; applying dynamic panel techniques would be more appropriate in that case, although they pose additional challenges. In addition, they use fixed effects and a lagged dependent variable in the same estimating models. This is a mis-specification of the econometric model. In this case the regressors are correlated with the error term by definition, and this leads to an inconsistent estimate of the parameters of interest. Third, including all four globalization variables simultaneously might give rise to multicollinearity problems. Fourth, inflation, income per capita, and GDP growth are also likely to be endogenous. Finally, since one channel through which globalization or trade may affect democracy is through its impact on economic development, coefficient estimates on the globalization variables when including income per capita as a regressor do not take account of that potential channel.

Bussmann (2001) sets up a simultaneous equation framework to understand the interplay between trade openness, democracy, economic growth and peace, although her focus is on the latter variable. The author does not find a significant impact of globalization on democracy. She uses two-stage least square techniques to account for the endogenous relationship between 
the four variables. The author chooses instrumental variables that do not appear to be valid, from our perspective. In the regressions in which democracy is the dependent variable, she instruments openness, economic growth and her measure of peace with the log of population, GDP per capita, investment, and government consumption among others. With the possible exception of population, all of these are arguably affected by democracy and are, therefore, not valid instruments. For example, we have already argued that several authors found a causal impact of democracy on growth. Bussmann also includes GDP per capita as a regressor and therefore our previous criticism on this point applies to her work.

Rigobón and Rodrik (2004) look at the interrelationship between democracy, rule of law, openness, and growth, and find that trade openness has a negative impact on democracy. They rely on identification through heteroskedasticity (see Rigobón (2003)) to sort out the two-way causal relationship between the four variables. Although we feel that Rigobón and Rodrik's paper has better methodological foundations than the two previous papers, we also believe their approach should be taken with caution. First, there are conceivably other variables that should have been incorporated in the analysis; their omission might affect the estimated results. For example, in our earlier review of theoretical literature, we highlighted the potential role played by income and asset distribution as a determinant of democracy. We argued that openness likely affects income distribution; the converse is probably also true. Moreover, inequality is deemed to have a pernicious effect on economic growth. In a two-stage least squares framework like the one we use in this paper and describe in the next section in more detail, as long as the instruments are not correlated with other variables that might affect the regressand, such as income inequality, omitting those variables from the regression should not be a cause for concern. It is not clear that the identification through heteroskedasticity methodology is immune to such omissions. A second concern has to do with the robustness of the results. For example, Rigobón and Rodrik (2004) find that openness also has a negative impact on income levels. However, Ha Yan Lee, Luca Antonio Ricci, and Rigobón (2004), who also apply the identification through heteroskedasticity methodology, come to the opposite conclusion. A last cause of concern is that Rigobón and Rodrik (2004), given the methodology they used, must 
assume that the estimated impact of openness on democracy is the same for all countries, which is a common assumption in cross-country studies. The results we present below, however, show that openness may have a differential impact on democracy which varies by region, for example. In view of the above concerns, we find Rigobón and Rodrik's finding of a negative impact of openness on democracy provocative, but deserving of an in-depth look.

As we describe in the next section, the main difference between our paper and previous studies lies in the methodological approach for dealing with the endogeneity between the globalization of trade and democracy. Before describing our econometric strategy, we should perhaps emphasize two additional aspects that distinguish our work from the existing empirical studies. First, by looking at three different historical periods, our paper exploits data on a number of experiences and variation in both the level of international integration and of democracy. For instance, the years between 1870 and 1913 witnessed rapid integration in the world economy stimulated in part by liberal trade policies, falling shipping costs, economic growth, improved communication infrastructure and decreasing transaction costs of international trade associated with the spread of the gold standard. ${ }^{6}$ It is natural to wonder whether these factors had anything to do with the fact that at roughly the same time many western countries extended the franchise to larger segments of society. Also, the interwar years saw attempts to re-build the international order of the late nineteenth century and a burst of interest in democratization associated with the creation of new countries after the War. Eventually the momentum fizzled and even reversed. The global trading system and capital markets imploded. Fascists and Bolsheviks stormed to power. Liberal democracy lost ground. Because of this, the period is an excellent testing ground for our econometric model. One might ask if the countries with the most extensive commercial links with other countries avoided or delayed the downward spiral into authoritarianism beginning in the mid-1920s. While theory and observation suggests there should be a link between democracy and integration, our statistical techniques complement these approaches and work to find the reduced form association.

A second innovation in this paper is that we investigate the channels through which open trade might affect democracy. Are the impacts coming from strengthening procedural democ- 
racy, i.e., by guaranteeing that the executive is elected through free and fair elections? Are constraints on executive power more stringent as globalization proceeds? Are political participation and civil rights strengthened? We believe that such discussion is an important aspect that deserves consideration and ours is a first attempt in that direction.

\section{Empirical strategy}

The challenge for an empirical test of the above hypotheses is that there is, in all likelihood, a two-way causal relationship present. Mansfield, Milner and Rosendorff (2000) argue that democracies are more likely to enact free trade policies. In the other direction, international trade, as argued above, may lead to greater political freedoms. The sign of the endogeneity bias in a regression of democracy on openness would be ambiguous a priori. Also, in a democracy, interest groups may also be better able to obtain protection from foreign competition [Gene M. Grossman and Elhanan Helpman (1994)] and voters may even agree to impose import restrictions in order to help less-privileged social groups [Julio J. Rotemberg (2003)].

If there is in fact a simultaneous determination of political and trade outcomes, one possible approach in the absence of a plausible structural model is to find variables that determine trade flows but are not correlated with any other factors influencing the level of democracy. These could then be used as instrumental variables to isolate the impact of greater international trade flows on political outcomes. Such a technique avoids the simultaneity bias which would plague any regression analysis that attempts to explain democracy in terms of trade flows.

As appropriate instruments, we take an approach inspired by the Frankel and Romer (1999) study of the impact of trade openness on output per capita. This is a problem similarly affected by endogeneity. The methodology has been subsequently used by a number of papers including Frankel and Rose (2002), who study how currency unions, through their impact on trade, affect growth; Wei (2000), who examines the impact of openness on corruption and the quality of governance; and Frankel and Rose (2005), who look at the effect of trade on a country's environment.

Frankel and Romer used geographic variables - distance from other nations, land area, and 
information on waterway access - to estimate a country's "natural openness" through the gravity equation of trade. That is, these variables are used as regressors in an OLS regression where the dependent variable to be explained is exports and imports (relative to GDP) between any two countries. The predicted level of openness then serves as an instrument for the actual level of openness. The authors then estimated an instrumental variables regression with income per capita as the dependent variable and openness as an endogenous regressor.

In a similar fashion, we use a gravity equation, augmented with other variables not used by Frankel and Romer, to create an instrument for trade openness. Then we regress a country's democracy measure on trade openness using our predicted openness measure as an instrumental variable. Of course, other variables besides openness may influence a country's political status. Nevertheless, pinpointing the correct set of those other variables poses an important challenge in itself, and many would themselves be subject to endogeneity problems. ${ }^{7}$ As Ro-

drik (2000) has noted, democracy is a "meta-institution" which likely defines the effectiveness of other institutions - e.g., the rule of law - that shape economic outcomes. While this is an important line of research, as long as the geographic information we use to predict openness is not correlated with these omitted variables the relationship we estimate will not be biased because of these exclusions.

\subsection{Econometric Model}

Given the above, democracy in country $i$ during period $t$ might be a function of the following variables: the level of exports plus imports divided by GDP during the period $\left(\right.$ Openness $\left._{i t}\right)$; a $\left(1 \times K_{1}\right)$ vector, $x$, consisting of time-varying country-specific characteristics; and a $\left(1 \times K_{2}\right)$ vector, $z$, containing time-invariant country-specific characteristics.

Possibilities for time-invariant (or very slowly changing) characteristics that do not suffer from an endogeneity problem are colonial legacy, land area, ethnic or linguistic diversity or simple country indicator variables to control for unobservable characteristics such as culture. Time varying variables might include lagged values of the democracy measure and population. ${ }^{8}$ We also posit a possibly heteroscedastic and within country autocorrelated error term $u_{i t}$. The following equation summarizes the basic econometric model of interest: 


$$
\text { Democracy }_{i t}=\beta_{0}+\delta \text { Openness }_{i t}+x_{i t} \Psi+z_{i} \Gamma+u_{i t}
$$

where $\beta_{0}, \delta, \Psi$, and $\Gamma$ are vectors of parameters to be estimated. Model (1) may be subject to endogeneity or omitted variable bias, as discussed before, since openness could be correlated with the error term $u_{i t}$ or since variables that belong to $z_{i}$ might be omitted. To circumvent these problems, we need appropriate excluded instrumental variables for openness that are not correlated with any other possible omitted determinants of democracy not included in equation (1) but which are strongly correlated with trade openness. We use a two-step procedure to obtain such instruments.

First we estimate a gravity equation. The gravity equation is a powerful reduced form model of bilateral trade flows with a long theoretical and empirical history. An early example of a theoretical derivation of the equation we estimate is in Anderson (1979). Modern practical and theoretical applications and variations can be found in Anderson and van Wincoop (2003), Frankel (1998) and Frankel and Rose (2002). The augmented gravity equation we use has the following form

$$
\begin{aligned}
\ln \left(\frac{\text { Exports }_{i j t}+\operatorname{Imports}_{i j t}}{\operatorname{GDP}_{i t}}\right) & =G_{i t} \lambda_{t}+\omega_{i t}=\lambda_{0}+\lambda_{1 t}\left(\ln \left(\text { population }_{i t}\right)\right)+\lambda_{2 t}\left(\ln \left(\text { population }_{j t}\right)\right) \\
& +\lambda_{3 t} \ln \left(\operatorname{area}_{i t}\right)+\lambda_{4 t} \ln \left(\operatorname{area}_{j t}\right)+\lambda_{5 t}\left(\ln \left(\text { distance }_{i j t}\right)\right) \\
& +\lambda_{6 t}\left(\text { border }_{i j}\right)+\lambda_{7 t}\left(\operatorname{landlocked}_{i j}\right) \\
& +\lambda_{8 t}\left(\text { island }_{i j}\right)+\lambda_{9 t}\left(\text { language }_{i j}\right)+\omega_{i j t}
\end{aligned}
$$

where $G_{i t}$ is a $(1 \times 9)$ vector of explanatory variables, distance is the great-circle distance between two countries' geographic centers measured in kilometers and is a proxy for the size of transportation costs, border $_{i j}$ equals one if country $i$ and country $j$ share a border and is also a proxy for transportation and information costs, landlocked takes on the values 0,1 or 2 depending on whether neither, one or both countries are on a major body of water, island (defined similar to the landlocked variable) indicates whether the countries are islands, language 
is 1 if there is a dominant or official language shared by both countries and 0 otherwise, the other variables are naturally interpreted and $\omega_{i t}$ is a homoscedastic white noise error term. ${ }^{9}$

We estimate the vector of coefficients, $\lambda_{t}$, separately for each year. When we pool the data this allows our instrument to vary somewhat over time both because some of the included variables can change over time and because the parameters collected in $\lambda$ vary over time. The latter might happen for instance if the way in which distance affects trade varies over time say due to technological innovations in transportation and communication.

We then predict the logarithm of bilateral openness for each country pair at each date for which we have all explanatory variables. For each country we then arrive at the level of predicted or "natural" trade openness, our instrument for actual trade openness, by taking the exponential of the predictions and adding up over all other trading partners:

$$
\text { predicted openness }=\widehat{T}_{i t}=\sum_{j \neq i} \exp \left[G^{\prime} \widehat{\lambda}_{t}\right]
$$

where $\widehat{\lambda}_{t}$ is the OLS estimate of the vector of coefficients in equation (2). Note that we can actually predict trade even for countries for which we have geographical data but not bilateral trade data. As usual $\widehat{T}_{i t}$ is uncorrelated with the residuals from the regression and hence incorporates only the geographic and technological determinants of trade. ${ }^{10}$ These combinations of variables would seem to be uncorrelated with other possible determinants of democracy.

\subsection{Data}

We refer the reader to the data appendix for a full description of our sources and methodology for implementing the different econometric specifications. Here we outline the basic characteristics of the data.

To estimate our gravity equation we used trade data from López Córdova and Meissner (2003) and Barbieri (1996) prior to 1913; Barbieri (1996) and Ritschl and Wolf (2004) for the interwar period; and Rose and Glick (2001) for post-1960. ${ }^{11}$ We also supplemented the Rose and Glick trade data with the IMF's Direction of Trade Statistics and missing GDP and population data from the World Bank's World Development Indicators data base. Where possible we 
use PPP-adjusted output. Post-1960 the PPP adjustment factors come from the World Bank's World Development Indicators; the interwar period uses Maddison's PPP-adjusted GDP. Trade is expressed in US dollars as in the original sources and converted to real values for our two latter samples. Prior to 1910 we divide real trade values by real GDP.

To measure democracy, we use the polity score from the Polity IV data set (described by Marshall and Jaggers (2000)). The polity score summarizes different indicators of political authority patterns in order to measure three aspects of a country's political system:

1. Competitiveness and openness in the process of executive recruitment, reflecting, for example, whether the head of government is selected through hereditary succession, or by designation of the ruling political elite; or through free and fair elections among candidates from different political parties and in which all citizens have the opportunity to become the executive.

2. Constraints on the chief executive, or the extent to which the head of government must take into consideration other points of view during the decision making process, such as those of a legislature.

3. Competitiveness and regulation of political participation, measuring the degree to which political competition is institutionalized (e.g., through major political parties that are stable and enduring) and is free from government control (e.g., free and fair elections, respect for human rights and civil liberties).

A weighted sum of the component variables is taken, and two new variables, one measuring democracy and the other autocracy, are created. The democracy variables take the values 0,1 , $2, \ldots, 10$. The autocracy variables take the values $-10,-9,-8, \ldots, 0$. The Polity IV score is the sum of the eleven point measure of democracy and the eleven point measure of autocracy and, thus, it ranges from -10 to 10. Countries are only included in the Polity IV data set if they achieved independence by 1998 and had a population of 500,000 or more in 1998. Dependencies at any point in time are not included. 
We use the Polity IV measure because it appears to be the best available data set that measures deep political and institutional change over a long time and for a large number of nations. As a check we carry out a similar analysis using the binary measure of democracy created by Alvarez, Cheibub, Limongi and Przeworski (2000). Other measures such as Polyarchy measure only participation rates in elections, while Freedom House measures information relevant to economic and political liberties at the personal level and is only available from 1973. Nevertheless we are aware that any attempt to measure the level of democracy is fraught with conceptual and mechanical problems or inaccuracies. ${ }^{12}$

\section{Results}

Below we show that there is ample, but not incontrovertible, evidence for a sizeable positive relationship between trade openness and democracy. For the interwar and post-1960 period, our econometric evidence suggests that switching from complete economic autarchy to the median level of (PPP-adjusted) openness could, in the long run, raise a country's polity score by as much as three or four points. In other words, in the year 2000, such opening up to trade could have transformed Russia, Venezuela or Indonesia into a full-fledged democracy with a polity score equivalent to that in the US, France or Great Britain. ${ }^{13}$ The relationship is also statistically significant and positive but less precisely estimated prior to 1913. Still, the point estimates suggest that a change in openness seems to have a similar impact over all three historical periods.

Though our results are fairly robust, some specifications suggest that we have found a spurious correlation. We use various panel techniques and also year-by-year cross-sectional regressions to identify the coefficient on openness. Our regressions are forced to rely on cross-sectional variance for identification and hence the data reveal more about the long-run equilibrium relationship of interest than the dynamic impact of opening up on democratization.

In a panel setup that allows for general country fixed factors or country fixed factors and persistence in regime choice, the relationship disappears in statistical and substantive terms. We believe this is because our variables of interest, including our instrument, do not sufficiently 
vary over time within countries. This impedes us from disentangling the impact of opening up to trade from the influence of unknown fixed factors or country specific unobservables. We do however make an attempt to control for certain identifiable fixed factors and still find some evidence of a positive relationship.

\subsection{Instrument Validity}

As described above, we use the estimated gravity model separately for each year of our sample to predict dyadic trade relative to output as in equation (3). The results from this "first stage" regression are reported in Tables 1 and 2. The gravity model itself fits the data very well, the signs and sizes of the coefficients make economic sense and are mostly comparable to other studies. One difference between the earlier periods and the latter periods is that land areas are either positively correlated or statistically unassociated with trade.

As instruments, the predicted values of openness seem extremely powerful. Indeed Tables 3 and 4 show that predicted openness is always highly statistically significant in a regression of actual openness on this variable. In fact, the t-statistic on the key excluded instrumentpredicted openness-is always larger than 2.7. The F-statistic is often an order of magnitude larger. In the year-by-year regressions, it is also usually much larger than this. It is often on the order of six or larger in the 1960-2000 period, and in the pooled data it is never smaller than 16 and as large as 42 . The predictive power and the correlation between our instrument and openness is relatively weaker but still quite strong when including controls for country size as column (3) from Table 3 shows.

We also tested the exclusion restriction that the geographic information incorporated in the gravity equation was uncorrelated with the error term with Hansen's J-statistic (a test for overidentifying restrictions that is robust to heteroscedasticity). This is actually a delicate matter because the equation of interest is just identified if natural openness is the only excluded instrument.

To resolve this we extracted the key regressors used for the gravity equation from the dyadic trade data set. For those variables that are defined at the dyad level, we generated simple averages or sums. For example, for distance we created the logarithm of the average distance 
to all trading partners. For the border and common language indicators, we generated the total number of borders and the number of countries with which the home country shared an official language. We have done the summation over the dyads with non-missing trade values. Our list of instruments that could potentially be correlated in the error term or have a direct effect on the level of democracy is then average distance to all trading partners, the logarithm of land area, the logarithm of population, the number of borders, the number of countries with a common language, and island indicator, and an indicator if the country is landlocked.

The findings are overall encouraging. First, for each period, in a pooled panel model without fixed effects and when we include all of these variables as excluded instruments we soundly reject the exclusion restrictions. Specification checks found that when we include population, land area, number of borders and the landlocked indicator directly and use only the average distance to countries and the island indicator as excluded instruments we can never reject the null hypothesis of exogeneity. It would appear that the variables besides distance and being an island matter directly for the determination of the level of democracy. We believe this could very well be because of the same logic that dictates we should include land area and population in the second stage regressions. We would also argue that inclusion of these variables will lead to consistent estimates as they seem exogenous in terms of the level of democracy. The logic for including these variables would be that countries with few borders and those that are not landlocked are also larger than the average country. Hence they substitute internal trade and commerce for international trade. If it is commercial interactions that matter then it could be important to specify the model in this way.

A few other observations are worth making here. In year-by-year cross-sectional regressions the list of variables in question (except population and land area) usually appear to be exogenous. ${ }^{14}$ This is opposite to what happens when we pool the data. However, this is not the case for a period spanning roughly 1965 to the mid-1980s where the overidentification tests tell us the same as in the pooled setup. ${ }^{15}$ Another more formidable problem with extracting these underlying factors and using them as the excluded instruments (or even using only the subset that appear exogenous as the excluded variables) is that a) we lose the important information 
incorporated in the vector of parameters estimated in the gravity equation and b) the gravity relation breaks down. The latter happens because in the first stage we are predicting the level of openness with an atheoretical list of variables in a log-linear specification. Both of these factors combine so as to make this list of variables extremely weak in the year by year regressions. To counter all of these problems, the approach we take is to continue using predicted openness as the only excluded instrumental variable and to control directly for the factors that seem suspect according to the tests of overidentifying restrictions. In this way, identification of the effect of openness on democracy will come from that part of natural openness which is uncorrelated with the included exogenous variables.

We have chosen to present estimates of the panel models and then to present regressions for single selected years for comparison. For the post-1960 period and from 1870 to 1913 we provide results every five years. For the interwar period, more data was available for certain years, and so we present results from those years. ${ }^{16}$

Our key results use various panel data techniques which provide different ways to look at the data. Our main results use three common specifications: country "random effects", country "fixed effects" and a partial adjustment model which allows for a lagged dependent variable. We also ran GMM and instrumental variables regressions on the first differenced data to control for fixed effects and to allow for the lagged dependent variable. A word about each type of model and our justification for using it is in the econometric appendix.

\subsection{Pooled Data Results}

With these considerations in mind, we estimate equation (1) both controlling and not controlling for endogeneity. Tables 5 and 6 present various specifications. First observe that a univariate OLS regression of polity on openness shows a statistically significant and positive relationship in all three time periods. ${ }^{17}$ Comparing instrumental variables estimates from column (2) to OLS estimates in column (1) for all three sub-tables suggests the OLS coefficient is biased slightly downward. This could happen for example if openness had measurement error and only roughly proxied democracy-enhancing interactions. Alternatively it could simply be sampling error as Frankel and Romer suggested. 
To check the robustness of the univariate results, we included various measures of a nation's size and also the troublesome landlocked, borders and shared language variables. Columns (3) and (4) show these results. In the 1960-2000 period and the interwar period, our coefficient is positive and highly statistically significant. In the pre-World War I period, the coefficient is significant at the 93 percent level. Overall however, the qualitative results are quite similar to the simple specifications in column (2), so in further specifications below rely on this pared down model as a baseline. Using the coefficients from column (3), the magnitudes of the partial effects given a one standard deviation change in openness in the pre-World War I period, the Interwar period and the post-World War II period are four, five and three polity points respectively. This long-run comparability is interesting in its own right and could be suggestive of a structural relationship between the two variables. ${ }^{18}$

In contrast to these results, columns (4) through (6) which control for fixed country effects provide no evidence for any link between openness and democracy. ${ }^{19}$ The coefficient on openness is uniformly much smaller (even becoming negative prior to World War II) than in the random effects specifications, and they are not statistically significant at any conventional level. For skeptics of a positive relationship, the interpretation of columns (4) through (6) is that correlation between openness and even natural openness and unobservable or omitted variables or factors are responsible for generating the already discussed positive coefficients on openness from column (3) or (4). However, one should not immediately accept the idea that the positive relationship found in the random effects models is spurious.

The obvious reason that the fixed effects specification does not work is that for many countries our instrument for openness does not vary too much over time. Dickey-Fuller tests for predicted openness (unreported) show that for the vast majority of the countries we could not reject the notion that the levels were stationary. Most of the variation appears to be across countries rather than within countries. In this case it would not be wise to expect good identification from a fixed effects regression that relies on within country variation in the data. The key excluded instrument seems highly collinear with the included fixed factors. But it is itself based on factors which are time-invariant or are slowly changing. Moreover, it is a 
prediction of actual openness which also changes fairly slowly over time. At the same time, it does not seem sensible to say that our measure of proximity and geography are correlated in any substantive way to other unobserved or omitted factors. So a plausible conclusion is that there is a mechanical problem here. A reasonable approach in the absence of other instruments then is to rely on the estimates that come from cross-sectional identification either in a pooled sample or in the year-by-year regressions.

Nevertheless in columns (1) and (2) of Table 7 we drop the country dummies and include a number of time-invariant controls that the fixed effects could be capturing. These include the absolute difference between a country's latitude and zero, a measure of ethnolinguistic fractionalization (from Roeder 2001) as measured in the year 1985, indicators for petroleum and commodity exporting countries and regional indicators. We focus on the 1960-2000 period as such data is only readily available for these years. In column (1) we see that the coefficient on openness is much smaller than in Column (3) of Table 5, but it is still positive and highly significant. ${ }^{20}$ However, when we control for country size, the coefficient on openness diminishes in size and statistical significance so that it is statistically indistinguishable from zero. This is likely to be for the same reasons that plague the fixed effects regressions of Tables 5 and 6 . Moreover we would expect proximity to be negatively correlated if at all correlated with size. But instead the coefficient appears to be upward biased when omitting size controls.

Other notable results on the these new control variables suggest that countries further from the equator are more democratic while exporters of commodities and possibly petroleum may be less democratic after controlling for other factors. Also the data confirm that, conditional on a number of variables, the Middle East and Sub-Saharan regions are the least democratic in the world compared to the US and Canada while the Latin American/Caribbean countries, East Asia and Western Europe are somewhat less so relative to these two North American countries. Because it is not obvious why our instrument would be correlated with these fixed factors, except for the fact that these are slowly moving over time, and because these factors explain almost 60 percent of the variation in our instrument, Table 7 makes us more comfortable with the idea that trade openness has a role in determining political outcomes rather than unobservable 
factors or other obvious underlying fixed characteristics of countries. ${ }^{21}$

We also present two other types of dynamic specifications in Tables 5 and 6 . The "partial adjustment" model of columns (7) through (9) shows that the long-run impact of a change in openness is roughly approximated by the simple non-dynamic specification. For instance column (9) shows for the post-1960 period that the long-run coefficient is comparable to the estimate of column (3). It is calculated as $0.1\left(=\frac{0.004}{1-0.96}\right)$. For the interwar period, the long-run marginal impact appears roughly similar to what column (3) implies. Prior to World War I, the magnitude of the coefficient on openness varies between -0.002 and 0.006 and does not appear statistically significant. For the latter two periods however, these specifications suggest that there is a dynamic process underway and that adjustment of the polity level to changes in openness is cumulative rather than immediate as one might expect.

The Arellano-Bond/GMM and Anderson-Hsiao/IV estimates are in columns (10) and (11) of Tables 5 and 6 . We find very mixed results when we eliminate fixed factors in this way. Most of the time the coefficient is statistically indistinguishable from zero which echoes the results from the other fixed effects specifications. In the GMM specification, we could not reject the null hypothesis of no second order autocorrelation in the transformed error terms, and so we rule out the possibility that this problem has caused our estimator to be inconsistent. The reason we find a coefficient statistically indistinguishable from zero is again unclear. It is known that the Arellano-Bond procedure can produce weak estimates in a panel context with high persistence in the dependent variable. The problems of invariance in the instrument cited above also creep in here, so it is unclear how worthwhile these specifications are given the data structure.

In columns (3) through (6) of Table 7 we also control for the possibility of heterogeneous coefficients by region during the $1960-2000$ period. It is possible that cross-regional differences in the relationship could bias our aggregated estimates. We include separate slope coefficients on openness for a number of geographical regions. This is under the assumption that certain unobserved cultural or geographical variables could influence the connection between openness to trade and democracy in a similar way throughout the region. Our regions, as seen in Table 7, are South East and East Asia, Eastern Europe and Central Asian states, Middle East and 
Northern Africa, South Asia, Western Europe, Sub-Saharan Africa, Latin America and the Caribbean, and North America (consisting only of the United States and Canada). ${ }^{22}$

There appears to be a particularly significant positive relationship in Western Europe, North America, Latin America, South Asia and post-1989 Eastern Europe. ${ }^{23}$ The same cannot be said for the Middle East/North Africa nor for Sub-Saharan Africa. In both regions, the estimated coefficient is usually negative and statistically different from zero. If we include lagged values of the polity score, the coefficient signs stay the same, but we can only reject the null hypothesis of no relationship for Latin America, Western Europe and the US and Canada. ${ }^{24}$

Besides showing some regional differences in the relation, another lesson from Table 7 is that primary commodity and petroleum exporters do not benefit from the pressures to democratize arising from international trade. ${ }^{25}$ It would therefore tend to suggest that each dollar of international commerce is not equally beneficial for the process of democratization. This evidence would be compatible with the idea that increased competition in goods markets or Stolper-Samuelson effects in a two-factor model could force more competition in the political sphere.

\subsection{Robustness: Year By Year Results}

\section{Results: 1960-2000}

We present simple specifications similar to those above for various years so that the reader can see if the panel results are masking underlying changes in the relationship over time. ${ }^{26}$ For various baseline years, Table 8 presents OLS regressions and shows that there is a positive relationship between openness and democracy which is statistically significant at conventional levels between 1960 and 1975. Simple OLS suggests the coefficient decreases over time from 0.23 in 1960 to a low of about 0.05 in $1995 .^{27}$

Table 9 reports our year by year instrumental variables regressions. The relationship between international trade and democracy is positive but the coefficient tends to become less statistically significant over time. Up to 1980 it is significant at greater than the 90 percent level. The coefficient also changes magnitude somewhat from year to year and shows a tendency to be trending downwards (as in the OLS results) over time. 
In all years, the relationship is fairly substantive. In 1960, the estimated coefficient is at its maximum of 0.28. A one standard deviation increase in openness, or a move from autarchy to the median level of openness of 12 percent, would imply an increase in the polity score of three and a half points. This is equal to almost one half of the polity score's standard deviation. According to the polity rankings in 1960, this would have been equivalent to seeing the likes of Brazil or Turkey become as democratic as the US, the UK or the Netherlands.

In the year 2000, when the coefficient is at its estimated low, the marginal effect of opening up from autarchy to the median level of openness (i.e., 18 percentage points) would have been to increase the polity score by a much smaller but still substantive 0.72 points. This implies a beta coefficient of about 0.13 . In that year this would have been similar to moving from a polity score of 8 , as in Mexico or Senegal, to one with a polity score of 9 as in France, South Africa or India. ${ }^{28}$

\section{Robustness}

We included size variables in Table 10. The difference between the results here and the previous table is largest in 1960 and 1965. Controlling for country size also increases the statistical significance of the coefficient on openness in most years. Besides eliminating the already discussed bias, it appears to alleviate the excessive influence Singapore exerts on the results.

Ordered probit specifications for selected years appear in Tables 11 and 12. As mentioned above, this specification of the dependent variable is technically more correct, but whether the parameterization makes a difference in practice to the substantive results is the question. We follow techniques adapted from Rivers and Vuong (1988) to control for endogeneity. Our results are qualitatively similar to the two-stage least squares results. The coefficient is larger in earlier years and openness is associated with more democracy. In contrast to the linear regressions, the coefficient is also statistically significant at greater than the 95 percent level in all years except $1970 .^{29}$

Finally, our regressions use "generated instruments" as instruments rather than the geographic information itself. As in Wooldridge (2002 p. 117) the usual two-stage least squares 
standard errors are asymptotically correct under the assumption the parameters from the gravity equation are consistent and the correlation between the geographic information and the error term is zero. Nevertheless, we simulated the change in the standard error of the openness coefficient for small changes in the underlying geographic data. ${ }^{30}$ This allows us to gauge how much sampling error could be affecting the standard errors. To save on computation time, we chose to carry out such a simulation for 1960 and 1995. Doing so barely altered the standard errors on the coefficient on openness. For example, our simulations yielded an increase of 0.001 in the standard error of the openness coefficient in both years.

\section{Results: 1920-1938}

For the 1920s and 1930s, our regressions support the idea that naturally open countries or places where trade was more important were less likely to fall to authoritarianism. Table 8 shows that during the interwar period there is a highly statistically significant and positive relationship between openness and democracy when not controlling for endogeneity. The results here show that the coefficient on openness is much larger than that in the pre- and post-War eras. In many years the coefficient is between 0.3 and 0.5 . The marginal effect of a one standard deviation change in openness is measured as roughly four which is similar to that in the early post-1960 period.

Table 9 reports the instrumental variables regressions. The relationship between international trade and democracy is positive, highly statistically significant and larger than nearly all the year by year estimates after 1960. The estimated coefficient of 0.53 in 1928 implies a move from the median level of PPP-adjusted openness of 21 percent to 10 percent (a one standard deviation decrease) would imply a decrease in the polity score of roughly six points. In Finland for example openness fell from 31 percent in 1928 to 19 percent in 1931. The polity score fell from ten to four between these years. Of course other countries experienced falls in measured openness during the worldwide depression, but the econometrics suggest the countries with the largest falls in trade would be expected to succumb to increasing authoritarianism.

For this sub-period we also tried other specifications of these baseline regressions. We included controls for size in Table 10 and obtained larger more statistically significant coefficients 
on openness then those in Table 9. Here there is almost a one-for-one relationship between openness and the polity score. Ordered probit results produce positive coefficients (and increases in the polity score for increases in openness) that are also highly statistically significant in all years of the interwar period.

\section{Results: 1870-1913}

For the relatively limited nineteenth century sample, Table 8 shows that in many of our benchmark years there is a statistically significant and positive relationship between openness and democracy. ${ }^{31}$ Simple OLS suggests the coefficient on openness equals roughly $0.1 .{ }^{32}$ Statistical significance is higher in the latter years of this period suggesting that this first wave of globalization (which dates from at least the mid-nineteenth century) took time to provoke the initial stimulus to democracy's first major advance.

Table 9 reports instrumental variables regressions. The relationship between international trade and democracy is positive and statistically significant at better than the 90 percent level in four out of the nine years presented. In most years, the OLS coefficient seems to be biased downward compared to the instrumental variables regressions. The estimated coefficient of 0.1 implies that a move from autarky to the median level of openness of 38 percent would yield an increase in the polity score of roughly four points. According to the polity rankings in 1910, this would have been equivalent to seeing countries like Spain, Portugal or Denmark gain a polity score equal to the US or Canada.

We tried other specifications of these baseline regressions to test their sensitivity. Ordered probit results in Table 12 find some evidence that there is a positive relationship between democracy and openness. While the coefficient is positive and the marginal effects are too, in many years these are only statistically significant at about the 85 or 90 percent confidence level. One might attribute these imprecise results to the fact that the number of degrees of freedom are so small. Indeed, given the theoretical arguments and the other empirical evidence, we feel cautiously inclined to trust the point estimates and to downplay the large standard errors here. 


\subsection{Channels through which globalization affects democracy}

As in the existing literature, we have concentrated on looking at how trade openness affects an aggregate measure of democracy. Although we find some evidence that the latter is causally explained by the globalization of goods markets, the results presented thus far do not tell us through which channels the causal impact might take place. The Polity IV data set allows us to remedy such a shortcoming and to undertake an initial exploration of those channels.

As explained in section 3.2, our measure of democracy, the polity score, summarizes three aspects of a country's political system: (i) competitiveness and openness of executive recruitment; (ii) constraints on the chief executive; and (iii) competitiveness and regulation of political participation. We take a look at each of these aspects in turn and ask whether trade openness has a causal impact on them using the same econometric strategy that we used for the aggregate polity score. We concentrate on the 1960-2000 period.

Instrumental-variable regression estimates with pooled data (not shown) are qualitatively similar to those presented in Table 6 for the aggregate polity score. Each component of the polity score is significantly affected, in statistical terms, by trade openness, although significance disappears when we account for country size. Likewise, year-by-year results are, in general, in line with the results presented in Tables 8 and 9, suggesting that openness affects all of the components of the polity score but that statistical significance drops in recent years. Interestingly, however, our previous results using the aggregate polity score appear to be driven, in certain years, by the behavior of one of its particular components but not by all of them. For example, Table 13, which extends the results in Table 9, indicates that openness affects democracy in the year 2000 solely through its impact on the competitiveness and regulation of political participation; in contrast, in 1970 and 1985 openness only had an impact on executive recruitment and not on the other two components of the polity score.

In sum, while it is difficult to extract any unambiguous lessons from the above exercises as to the channels through which globalization affects democracy, our results suggest that the relative importance of those channels may be changing over time. This possibility may merit a further look in future studies. 


\section{Conclusions}

In this study we attempt to gauge the causal impact of trade openness on the level of democracy. To do so we construct a measure of "natural" openness and use it to see if countries that are more naturally open are more democratic. Indeed we find that open countries have consistently been more strongly democratic between 1895 and 2000 .

Our methods suggest that an autonomous move from autarky to the average level of openness could raise a country's democracy measure by somewhere between three and five points over the long-run. This is a substantial increase. To put this in perspective, this would have been comparable to seeing countries like Argentina, South Korea, Brazil or Romania (all with polity scores of 8) achieve a polity score similar to the US, the UK or France in the year 2000. There is no way to tell using our methodology if this effect would be similar if there was an actual policy change such as the ending of inward looking trade policies or the signing of trade agreements to lower tariffs. Our reduced form model suggests on average that it would be, but it is difficult to imagine such an experiment without other factors changing concurrently.

Interestingly there is evidence that the strength of the relationship is fairly constant over the long run, and changes in openness also seem to have a long-run impact on the level of the polity score rather than an immediate short-run effect. Further evidence has shown that there may be variation by region in the impact. Unfortunately, we cannot totally rule out that a set of as yet un-identified fixed or slowly changing country-level variables is responsible for the move to democratization.

Since our definition of democracy is based on the Polity IV data set it may not capture all aspects of a democratic system. For the cautious reader, our results might be interpreted as saying that openness raises competition in the recruitment of the executive, more open participation in choosing the executive and more checks and balances against an executive. While we gave an initial look at each of these aspects, future research should explore in more detail through which channels openness is affecting the polity score.

Given the components that the polity score measures, this study may shed light on the kind of theoretical model one would need to explain this process. The results may be in line with a 
story that argues that openness and more fierce competition in goods markets creates similar pressures in the political system. This is surely a promising avenue for further research both from a theoretical and an historical perspective.

Overall, the long-run patterns suggest a similar story for the period between 1870 and 1913, again between 1920 and 1939 and finally between 1960 and 2000. We believe there is adequate information available to argue that international trade or, at the very least, fundamental factors that drive openness to trade can help increase the process of building and consolidating democracy. 


\section{Econometrics Appendix}

Our random effects models assume that one part of the error term is idiosyncratic to the country, and, most importantly, that the country error is uncorrelated with the instrument, and other included or excluded regressors. Our fixed effects specifications allow us to relax this strong assumption and model any unobserved heterogeneity with a country specific intercept. The other benefit of this type of model is that it uses the variance over time in the data within a country to estimate the average relation between changes in openness to changes in democracy. The drawback is that if the regressors are uncorrelated with the country specific error component the estimates are inefficient and would tend to over-reject the null hypothesis of no correlation.

The partial adjustment model pools the data but allows for the influence of past outcomes by including the lagged value of the polity score. One natural interpretation of the partial adjustment model is that a country has a conditional target or optimal level of democracy, but that it is costly or difficult to adjust towards this level. The model hence allows for estimation of a short run-impact and a long-run impact on the level of democracy. ${ }^{33}$ For all of these specifications we make sure to use heteroscedasticity and autocorrelation robust standard errors.

We also present a generalized method of moments (GMM) estimation technique for dynamic panels with fixed effects made operational by Arellano and Bond (1991). This type of technique is precisely for panel data models that have the structure of equation (1) but which might include lagged values of democracy to control for the importance of historical regime choice. Note that if previous levels of democracy matter, a fixed effects panel regression is not valid in this case because of the correlation between the error term and the lagged values induced by the within transformation.

To obtain unbiased estimates of the coefficients, one first writes equation (1) in first differences as follows

$$
\begin{gathered}
\Delta \text { Democracy }_{i t}=\text { Democracy }_{i t}-\text { Democracy }_{i t-1}= \\
\widetilde{\beta}_{0}+\widetilde{\delta}\left(\Delta \text { Openness }_{i t}\right)+\sum_{k=1}^{T} \widetilde{\gamma}_{k}\left(\Delta \text { Democracy }_{i t-k}\right)+\Delta u_{i t}
\end{gathered}
$$

where the " $\Delta$ " is the difference operator, and we use the " " to distinguish the coefficients estimated in this model from those of equation (1). Notice that the variables that are constant over time (e.g., the country fixed effects) fall out of the equation, and so we control for these factors by taking the first differences. The lagged dependent variable terms are correlated with the new error term since the lagged error term appears in the differenced error term. To get around this, one uses plausible instruments for the lagged values of the dependent variable. Assuming we restrict the lag structure to include only the first-lagged difference of the democracy measure, then any previous lag from period $t-2$ and before would be viable. These values are highly correlated with lagged democracy but are uncorrelated with the error term. ${ }^{34}$

The GMM estimates gain efficiency by using a large number of "moment" restrictions and solve for the parameters on the basis of those restrictions. In particular the moment restrictions here are that the expectations of the cross products of the lagged values used as instruments and the error terms are zero. We use up to the fifth lag of the dependent variable as an instrument, the level and first difference of predicted openness and the second lag of actual openness in the instrument set. Our justification for including the second lag of actual openness is that this variable can be considered predetermined and hence not correlated with the error term. ${ }^{35} \mathrm{We}$ use Stata and also reproduced our results in $O x$. The details on estimation methods are given in the Stata User's Manual.

Anderson and Hsiao (1982) performed a similar regression using only the second lag as an instrument for the lagged difference. Arellano and Bond (1991) pointed out that using many more lags as instruments could increase the efficiency of the estimation. We present Anderson Hsiao type estimates for comparison. 


\section{Data Appendix}

\section{Democracy}

1870-2000: We use the polity measure from the Polity IV data set. We classify this variable as missing if there is an interruption, interregnum, or transition. See the discussion in the text and the Polity IV manual for insight into how this variable is constructed.

\section{Openness}

1870-1913: Exports and imports were taken from Barbieri (1996), López Córdova and Meissner (2003) and Mitchell (1992, 1993 and 1995) . GDP come from the data set underlying López Córdova and Meissner (2003). Some additional nominal GDP and total trade values were taken from the data set used in Obstfeld and Taylor (2003). Nominal imports and exports were divided by the nominal value of GDP to arrive at an openness measure.

1917-1940: Exports and imports in dollars were taken from Barbieri (1996) and Mitchell (op. cit.). Nominal GDP data come from Eichengreen and Irwin (1995), Mitchell (op. cit.), Obstfeld and Taylor (2003), and Ritschl and Wolf (2003). Real PPP-adjusted GDP is available from Maddison (2001). For real-PPP adjusted openness we inflated current values of exports and imports to 1990 values using the US CPI from www.freelunch.com. We then divided these values by Maddison's GDP values.

1960-2000: Total trade in dollars comes from Rose (2003) supplemented by data from the IMF International Financial Statistics and the World Bank's World Development Indicators. We reflated trade using a US CPI available from www.freelunch.com. We divided these real values of trade by GDP values from the Penn World Tables supplemented by the World Development Indicators. To make the PPP adjustment, we used the GDP price level factor from the World Development Indicators to account for local deviations of the price levels.

\section{Gravity Regression Components}

\section{Bilateral Trade}

1870-1913: Bilateral trade comes from López Córdova and Meissner (2003). We divided current dollar value bilateral trade by nominal current dollar values of GDP. Using PPPadjustments made the regressions of interest infeasible.

1917-1940: Bilateral trade comes from Barbieri (1996) supplemented by Ritschl and Wolf (2003). We converted trade to real 1990 values using a CPI for the US and divided these values by Maddison's PPP-adjusted GDP.

1960-2000: Bilateral trade comes from Rose (2003) supplemented by the IMF's Direction of Trade Statistics. We use the average of exports and imports as reported by both countries in a country pair rather then the average of all four possible values as in Rose (2003). We converted trade to real values as described above and divided by PPP-Adjusted GDP.

GDP

See previous notes on openness.

\section{Population}

1870-1913: Data come from López Córdova and Meissner (2003).

1917-1940: Populations come from Mitchell (op. cit.) supplemented by data from Eichengreen and Irwin (1995).

1960-2000: Population comes from the World Bank's World Development Indicators.

Land Area This is measured as the logarithm of square kilometers.

1870-1913: López Córdova and Meissner (2003)

1917-1940: Stinnett, Tir, Schafer, Diehl, and Gochman (2002)

1960-2000: Rose (2003)

Bilateral Distance

1870-1913: López Córdova and Meissner (2003)

1917-1940: Eichengreen and Irwin (1995)

1960-2000: Rose (2003)

Shared Border Indicators

1870-1913: López Córdova and Meissner (2003)

1917-1940: Eichengreen and Irwin (1995) 
1960-2000: Rose (2003)

Landlocked Indicators

1870-1913: López Córdova and Meissner (2003).

1917-1940: Eichengreen and Irwin (1995)

1960-2000: Rose (2003)

Island Indicator

All years come from Rose (2003)

Common Language

1870-1913 and 1917-1940: López Córdova and Meissner (2003)

1960-2000: Rose (2003) 


\section{Notes}

${ }^{1}$ See Dani Rodrik $(1997,2000)$ for an overview. On economic growth, see John F. Helliwell (1992), Robert J. Barro (1996), Rodrik (1999) and Peter H. Lindert (2003). On income and asset distribution, see Daron Acemoglu and James A. Robinson (2000) and Lindert (2003).

${ }^{2}$ Vivid illustration of such belief are remarks by former US President William J. Clinton arguing that "[j] ust as democracy helps make the world safe for commerce, commerce helps make the world safe for democracy. It's a two-way street;" (from Between Hope and History, Bill Clinton, p. 36, Jan 1, 1996, as cited in http://www.issues2000.org/Celeb/Bill_Clinton_Free_Trade.htm; downloaded on 27 November 2004); and by his successor, George W. Bush, who claims that "when we promote open trade, we are promoting political freedom. Societies that open to commerce across their borders will open to democracy within their borders, not always immediately, and not always smoothly, but in good time." (quote taken from Office of the Press Secretary, The White House, "Remarks by the President to the Council of the Americas", May 7, 2001; downloaded on 8 May 2001 from http://www.whitehouse.gov/news).

${ }^{3}$ For a reply to this view, see Jeffrey D. Sachs (2003), who argues in favor of the role of geography in explaining income per capita. Edward L. Glaeser, Rafael La Porta, Florencio Lopez-de-Silanes and Andrei Schleifer (2004) also downplay the importance of institutions in explaining growth.

${ }^{4}$ See Pinelopi Koujianou Goldberg and Nina Pavcnik (2004) for a recent review of the literature.

${ }^{5} \mathrm{See}$ Li and Reuveny (2003), Table 2.

${ }^{6}$ See for example O'Rourke and Williamson (1999), Estevadeordal, Frantz, and Taylor(2003), López-Córdova and Meissner (2003) and David S. Jacks (2004).

${ }^{7}$ For example, it is compelling to think that the level of democracy is positively related to schooling levels. However, schooling itself is likely to be influenced by the political regime.

${ }^{8}$ An important point that Frankel and Romer made is that controls for size were necessary. Smaller countries are naturally more proximate to other countries and also engage in more international and less intra-national trade. If trade and exchange in general (i.e., the overall size of the economy), rather than international trade affected the amount of democracy, our instrument could be negatively correlated with the error term if we omit such controls and therefore our point estimate could possibly be biased downward. Therefore, key controls may be population and land area.

${ }^{9}$ We make land area and distance a time-varying variable. In principle, if the area of a country changes, then the geographic center of a country may also change. It turns out that we do not have too many observations with full data that change bilateral distance or area within our samples.

${ }^{10}$ We assume a homoscedastic error process for equation (2). If we do not then $\widehat{T}_{i t}$ will be multiplied by a pair-specific residual, and this would affect our parameter of interest. Assuming 
homoscedasticity makes it so that a constant pre-multiplies all of the instruments and hence will not affect our instrumental variables regressions.

${ }^{11}$ The latter is available on line at http://faculty.haas.berkeley.edu/arose/RecRes.htm.

${ }^{12}$ Treir and Jackman (2003) provide a recent analysis of some important issues and provide measures of the latent value of democracy. These variables could be of interest as a dependent variable in further study.

${ }^{13} \mathrm{We}$ are aware that this comparative static is only an approximation. One problem with this is that categorical coding of the dependent variable makes it generally technically incorrect to suppose that incremental changes are uniform across the interval. Ordered probit analysis we undertake below helps us to be more precise about this.

${ }^{14}$ These results are available upon request.

${ }^{15}$ One possibility is that the nature of the process of democratization has changed over time. This is plausible. Huntington's "third wave" does not really begin until the late 1970s. It could also be the case that if these factors are nearly time invariant or highly persistent (as most are) they end up being naturally correlated with other unobservables.

${ }^{16}$ We have in fact carried out these specifications every five years between 1870 and 1910 (the only years for which we have data) and for all years between 1920 and 1939 and 1960 and 2000 . Reporting only benchmark years does not change the qualitative results reported below.

${ }^{17}$ Our results differ from Bussman (2001) because she uses different instrumental variables than we do. Her results appear to rely mainly on population growth rates to instrument for openness. Contrary to Li and Reuveny (2003) we find a positive coefficient. This is possibly because of their use of fixed effects with a lagged dependent variable which is a mis-specification given the structure of the data. They also include other variables likely to be endogenous but do not correct for this problem either.

${ }^{18}$ Singapore is an extreme outlier for the 1960-2000 sample. In each year it massivley influences the results compared to its relative importance on the global scene. Taking Singapore out changes our results drastically: in the specification of column (3) the coefficient is estimated at 0.21 and has a standard error of 0.01 while the other coefficients are qualitatively similar.

${ }^{19}$ We do not run a panel "fixed effects" regression with the lagged value of polity as in Li and Reuveny (2003). The presence in equation (1) of fixed effects indicators coupled with a lagged dependent variable would present an econometric problem even if there were no autocorrelation in the error term. To see why, one uses the notion that the fixed effects panel estimator can be written as a model where all the regressors are in terms of deviations from individual mean values. One immediately sees that the error term in this specification is a function of all periods' error terms, and because of this, the lagged dependent variable is correlated with this error term.

${ }^{20}$ In a regression of our instrument on the fixed factors included in Table 7 column (2) and year indicators, the R-Squared is roughly 0.6 . This is another way to say that the instrument is fairly fixed over time and the root of our multicollinearity problems.

${ }^{21}$ We also included the average polity score of each country's Politically Relevant International 
Environment (PRIE) and output per capita. We instrumented the latter with distance from the equator. We define the PRIE as the US, the UK, France, and the USSR (or Russia after 1990). We include China if the country is in Asia. In the PRIE score we also include the polity score of all countries that are less than 601 miles from the home country. In the yearby-year specifications with this variable we ran, we found that openness is positively related and statistically significant at better than the 90 percent level up to 1980 . Output per capita is always positive and significant as is the PRIE polity score. In a panel specification, openness is negative and significant or negative and insignificant depending on the particular specification. Still, the lack of convincing instruments for output per person and the econometric identification problem associated with neighborhood effects as outlined in William A. Brock and Steven N. Durlauf (2003) persuaded us not to report these specifications. While we are aware that the non-linear ordered probit model may identify the regional effects, we are cautious because of the remaining "selection" issues and because the instrument for openness does not seem related to the regional average choices.

${ }^{22}$ Prior to 1990 the countries for which we have data in the Eastern Europe region are Poland, Hungary, Romania and Turkey.

${ }^{23}$ If we leave out Singapore, East Asia also has a large, statistically significant and positive relationship.

${ }^{24}$ We also allowed for different slopes by region both for openness and lagged polity. The results are qualitatively similar to those of Table 7 where we allow for regional variation in the coefficient on openness.

${ }^{25}$ When we control for whether a country is a primary commodity exporter or a petroleum exporter by interacting these variables with openness in the baseline two-stage least squares regression, results show that these types of countries have significantly lower polity scores.

${ }^{26}$ Below we present ordered probit results for selected years. This type of model, strictly speaking, may be more appropriate for the structure of our dependent variable. We are also comfortable using continuous dependent variable techniques because, as the number of categories becomes large, ordered probit and linear models produce very similar results and because the predictions we get from our model are very nearly within the bounds of the actual outcomes.

${ }^{27}$ Again, Singapore is an extreme outlier. In each year it overly influences the results compared to its relative importance on the global scene. Taking Singapore out changes our results slightly up to 1980 and significantly after 1980 . When we take it out, the coefficient on openness is highly statistically significant up to 2000 and does not show a secular decline.

${ }^{28}$ We also ran instrumental variables regressions with a quadratic term for openness including Singapore adding the square of predicted openness to our instrument list. Results are qualitatively very similar to (un-reported) results which left Singapore out. The total partial effect (evaluated at the mean of openness) ranges from a high of 0.50 in 1970 to a low of 0.14 in 2000. Nevertheless, the sum of the coefficients in the polynomial are statistically significant only from 1970 onwards which suggests a more linear relationship prior to the 1970s when global trade had yet to fully take off.

${ }^{29}$ As mentioned above, we used the binary data from Alvarez et. al. in an instrumental 
variables probit model including simply openness but also controls for country size and GDP per capita. Their data is available from 1960 to 1990. The results show a highly significant and positive relationship between democracy and openness. It would appear that the general positive correlation is not too sensitive to the way in which we code the democracy variable.

${ }^{30}$ Essentially we allow each variable in the gravity equation to increase by 0.001 and generate a new value of predicted trade. We then redo the instrumental variables regression to see how the standard error of our coefficient changes. See Frankel and Romer (1999) for a precise explanation.

${ }^{31}$ The countries in our 1910 sample are Great Britain, France, USA, Belgium, Switzerland, Italy, Germany, Denmark, Norway, Sweden, Austria, Russia, Spain, Portugal, Greece, Australia, Canada, Japan, Brazil, Mexico, Chile, Argentina and New Zealand.

${ }^{32}$ There are also a few outliers in this period with openness greater than 110 percent. Excluding the Netherlands from 1880, Switzerland in 1880 and Chile from 1880 to 1890 changes the simple linear model results drastically. The coefficients on openness are larger and more significant after 1890. However, including a quadratic for openness yields OLS results very similar to those found excluding these outliers.

${ }^{33}$ To see if an error correction type model was feasible we also tried even more general time-series specifications which included various lags of both openness and the polity variable. However, the data did not satisfy the necessary criterion to run a simple univariate error correction model that the sum of the coefficients on the first lag of polity and the contemporary and lagged value of openness was statistically indistinguishable from one.

${ }^{34}$ This of course assumes there is no higher order autocorrelation in the error terms which one can in fact test as we do below. There does not appear to be any once we control for lagged values of the dependent variable.

${ }^{35}$ Arellano and Bond (1991) and Baltagi (1995) give the precise definitions for the general case of the estimators we are interested in. Also if we leave out the lag of actual openness we find similar results. 


\section{References}

Acemoglu, Daron and James A. Robinson, "Why Did the West Extend the Franchise? Growth, Inequality and Democracy in Historical Perspective," Quarterly Journal of Economics, 2000, 115, 1167-1199.

- and - , "A Theory of Political Transitions," American Economic Review, September 2001, 91 (4), 938-963.

- and - "Political Origins of Dictatorship and Democracy," Book Manuscript 2003. University of California, Berkeley.

Alcalá, Francisco and Antonio Ciccone, "Trade and Productivity," Quarterly Journal of Economics, May 2004, 119 (2), 613-646.

Alvarez, Mike, José Antonio Cheibub, Fernando Limongi, and Adam Przeworski, Democracy and Development: Political Institutions and Material Well-Being in the World, 1950-1990, Cambridge: Cambridge UNiversity Press, 2000.

Anderson, James E., "A Theoretical Foundation for the Gravity Equation," American Economic Review, 1979, 69 (1), 106-116.

- and Eric van Wincoop, "Gravity with Gravitas: A Solution to the Border Puzzle," American Economic Review, March 2003, 93 (1), 170-192.

Anderson, T.W. and Cheng Hsiao, "Formulation and Estimation of Dynamic Models Using Panel Data," Journal of Econometrics, 1982, 18 (1), 47-82.

Baltagi, B.H., Econometric Analysis of Panel Data, Chichester, UK: John Wiley and Sons, 1995.

Barbieri, Katherine, "Economic Interdependence and Militarized Interstate Conflict, 1870-1985." PhD dissertation, Binghampton University 1996.

Barro, Robert J., "Democracy and Growth," Journal of Economic Growth, 1996, 1 (1), $1-27$.

- , "Determinants of Democracy," Journal of Political Economy, 1999, 107 (6, pt. 2), 1-27.

Bhagwati, Jagdish, In Defense of Globalization, New York: Oxford University Press, 2004.

Boix, Carles and Susan C. Stokes, "Endogenous Democratization," September 2002. Unpublished Manuscript, The University of Chicago.

Borraz, Fernando and Ernesto López-Córdova, "Has Globalization Deepened Income Inequality in Mexico?," August 2004. Unpublished manuscript, Inter-American Development Bank.

Brock, William A. and Steven N. Durlauf, "Multinomial Choice with Social Interactions," Working Paper t0288, National Bureau of Economic Research June 2003.

Bussmann, Margit, "Examining Causality Among Conflict, Democracy, Openness, and Economic Growth," 2001. Mimeo, University of Alabama.

Eichengreen, Barry and Douglas Irwin," "Trade blocs, currency blocs and the reorientation of world trade in the 1930s," Journal of International Economics, 1995, 38, $1-24$.

Estevadeordal, Antoni, Brian Frantz, and Alan M. Taylor, "The Rise and Fall of World Trade, 1870-1939," Quarterly Journal of Economics, 2003, 118, 359-407.

Frankel, Jeffrey A. and Andrew K. Rose, "An Estimate of the Effect of Currency Unions on Trade and Growth," Quarterly Journal of Economics, May 2002, 117 (2), 437-466.

- and - , "Is Trade Good for the Environment? Sorting Out the Causality," Review of Economics and Statistics, 2005, 87 (1).

- and David Romer, "Does Trade Cause Growth?," American Economic Review, June 1999, 89 (3), 379-399.

- , ed., The Regionalization of the World Economy, Chicago: Chicago University Press, 1998.

Glaeser, Edward L., Rafael La Porta, Florencio Lopez de Silanes, and Andrei Schleifer, "Do Institutions Cause Growth?," Working Paper 10568, National Bureau of Economic Research June 2004.

Goldberg, Pinelopi Koujianou and Nina Pavcnik, "Trade, Inequality and Poverty: What Do We Know? Evidence from Recent Trade Liberalization Episodes in Developing Countries," Working Paper 10593, National Bureau of Economic Research June 2004.

Grossman, Gene M. and Elhanan Helpman, "Protection for Sale," American Economic Review, September 1994, 84 (4), 833-850.

Heston, Alan, Robert Summers, and Bettina Aten, Penn World Table Version 6.1 
Center for International Comparisons at the University of Pennsylvania (CICUP) October 2002.

House, Freedom, Freedom House Country Ratings 2003.

Ianchovichina, Elena, Alessandro Nicita, and Isidro Soloaga, "Trade Reform and Household Welfare: The Case of Mexico," Policy Research Working Paper 2667, World Bank August 2001.

Jacks, David S., "What Drove Nineteenth Century Market Integration?," 2004. Mimeo, Simon Fraser University.

Lee, Ha Yan, Luca Antonio Ricci, and Roberto Rigobón, "Once Again, Is Openness Good for Growth?," Working Paper WP/04/135, International Monetary Fund July 2004.

Li, Quan and Rafael Reuveny, "Economic Globalization and Democracy: An Empirical Analysis," British Journal of Political Science, 2003, 33, 29-54.

Lin, Justin Yifu and Jeffrey B. Nugent, "Institutions and Economic Development," in Jere Behrman and T.N. Srinivasan, eds., Handbook of Development Economics, Vol. IIIA, Amsterdam: Elsevier Science B.V., 1995, chapter 38, pp. 2301-2370.

Lindert, Peter H., "Voice and Growth: Was Churchill Right?," Working Paper 9749, National Bureau of Economic Research June 2003.

Lipset, Seymour Martin, "Some Social Requisites of Democracy: Economic Development and Political Legitimacy," The American Political Science Review, March 1959, 53 (1), 69-105.

López-Córdova, J. Ernesto and Christopher M. Meissner, "Exchange Rate Regimes and International Trade: Evidence from the Classical Gold Standard Era," American Economic Review, 2003, 93 (1), 344-353.

Maddison, Angus, The World Economy: A Milennial Perspective, Paris: Development Centre of the Organisation for Economic Co-operation and Development, 2001.

Marshall, Monty G. and Keith Jaggers, Polity IV Project: Political Regime Characteristics and Transitions, 1800-1999 Integrated Network for Societal Conflict Research (INSCR) Program, Center for International Development and Conflict Management (CIDCM) December 2000.

Mitchell, Brian R., International Historical Statistics. Europe 1750-1988, New York: Stockton Press, 1992.

-, International Historical Statistics. The Americas 1750-1988, New York: Stockton Press, 1993.

-, International Historical Statistics. Africa, Asia \& Oceania 1750-1988, New York: Stockton Press, 1995.

Obstfeld, Maurice and Alan M. Taylor, "Sovereign Risk, Credibility and the Gold Standard: 1870-1913 versus 1925-31," Economic Jounral, April 2003, 113, 1-35.

O'Rourke, Kevin H. and Jeffrey G. Williamson, Globalization and History: The Evolution of a Nineteenth-Century Atlantic Economy, Cambridge, Massachusetts and London: The MIT Press, 1999.

Porto, Guido G., "Using Survey Data to Assess the Distributional Effects of Trade Policy," April 2003. Unpublished Manuscript, The World Bank.

Rigobón, Roberto, "Identification Through Heteroskedasticity," The Review of Economics and Statistics, November 2003, 85 (4), 777-792.

- and Dani Rodrik, "Rule of Law, Democracy, Openness, and Income: Estimating the Interrelationships," May 2004. Unpublished Manuscript, MIT and Harvard University.

Ritschl, Albrecht and Nikolaus Wolf, "Endogeneity of Currency Areas and Trade Blocs: Evidence from the Inter-war Period," Working Paper 4112, CEPR November 2003.

Rivers, Douglas and Quang H. Vuong, "Limited Information Estimators and Exogeneity Tests for Simultaneous Probit Models," Journal of Econometrics, November 1988, 39 (3), $347-366$.

Rodríguez, Francisco and Dani Rodrik, "Trade Policy and Economic Growth: A Skeptic's Guide to Cross-National Evidence," Working Paper W7081, National Bureau of Economic Research April 1999.

Rodrik, Dani, "Democracy and Economic Performance," December 1997. Harvard University.

- , "Where Did All the Growth Go? External Shocks, Social Conflict, and Growth Collapses," Journal of Economic Growth, 1999, 4 (4), 385-412.

- , "Institutions for High-Quality Growth: What They Are and How to Acquire Them," 
Working Paper 7540, National Bureau of Economic Research February 2000.

- , Arvind Subramanian, and Francesco Trebbi, "Institutions Rule: The Primacy of Institutions over Geography and Integration in Economic Development.," October 2002. Unpublished Manuscript, Harvard University.

Roeder, Philip G., "Ethnolinguistic Fractionalization (ELF) Indices, 1961 and 1985," Technical Report 2001. Downloaded from http//:weber.ucsd.edu/ proeder/elf.htm on 22 November, 2003.

Rose, Andrew K., "Do We Really Know that the WTO increases Trade?," American Economic Review, 2003. (forthcoming).

- and Reuven Glick, "Does a Currency Union affect Trade? The Time-Series Evidence," European Economic Review, June 2002, 46 (6), 1125-1151.

Rotemberg, Julio J., "Commercial Policy with Altruistic Voters," Journal of Political Economy, February 2003, 111 (1), 174-201.

Sachs, Jeffrey D., "Institutions Don't Rule: Direct Effects of Geography on Per Capita Income," Working Paper 9490, National Bureau of Economic Research February 2003.

Sen, Amartya, Development as Freedom, New York: Anchor Books, 1999.

Stinnet, Douglas M., Jaroslav Tir, Philip Schafer, Paul F. Diehl, and Charles Gochman, "The Correlates of War Project Direct Contiguity Data, Version 3," Conflict Management and Peace Science, 2002, 19 (2), 58-66.

Treier, Shawn and Simon Jackman, "Democracy as a Latent Variable," 2003. Mimeo, Stanford University.

Vanhanen, Tatu, The Polyarchy Dataset: Vanhanen's Index of Democracy 2000.

Wei, Shang-Jin, "Natural Openness and Good Government," Working Paper 7765, National Bureau of Economic Research June 2000.

- and Yi Wu, "Globalization and Inequality Without Differences in Data Definitions, Legal Systems and Other Institutions," October 2002. Unpublished Manuscript, International Monetary Fund.

Wooldridge, Jeffrey M., Econometric Analysis of Cross Section and Panel Data, London: MIT Press, 2002. 
Table 1: Gravity Equation Results, 1960-2000

\begin{tabular}{|c|c|c|c|c|c|c|c|c|c|}
\hline \multirow[t]{2}{*}{ Regressors } & \multicolumn{9}{|c|}{ Year } \\
\hline & 1960 & 1965 & 1970 & 1975 & 1980 & 1985 & 1990 & 1995 & 2000 \\
\hline \multirow[t]{2}{*}{ distance } & -0.65 & -0.72 & -0.94 & -1.10 & -1.14 & -1.24 & -1.30 & -1.17 & -1.27 \\
\hline & $(0.03)$ & $(0.03)$ & $(0.03)$ & $(0.03)$ & $(0.03)$ & $(0.04)$ & $(0.04)$ & $(0.03)$ & $(0.03)$ \\
\hline \multirow[t]{2}{*}{ In (area) country i } & -0.10 & -0.07 & -0.17 & -0.11 & -0.14 & -0.15 & -0.13 & -0.14 & -0.07 \\
\hline & $(0.02)$ & $(0.01)$ & $(0.02)$ & $(0.02)$ & $(0.02)$ & $(0.02)$ & $(0.02)$ & $(0.02)$ & $(0.02)$ \\
\hline \multirow[t]{2}{*}{ In (area) country j } & -0.12 & -0.12 & -0.19 & -0.12 & -0.14 & -0.21 & -0.23 & -0.25 & -0.12 \\
\hline & $(0.02)$ & $(0.02)$ & $(0.02)$ & $(0.02)$ & $(0.02)$ & $(0.02)$ & $(0.02)$ & $(0.02)$ & $(0.02)$ \\
\hline \multirow[t]{2}{*}{ In (population) country $i$} & -0.34 & -0.35 & -0.08 & -0.11 & -0.08 & -0.05 & 0.00 & 0.01 & -0.14 \\
\hline & $(0.02)$ & $(0.02)$ & $(0.02)$ & $(0.02)$ & $(0.02)$ & $(0.02)$ & $(0.02)$ & $(0.02)$ & $(0.02)$ \\
\hline \multirow{2}{*}{ In (population) country $\mathrm{j}$} & 0.74 & 0.75 & 0.92 & 0.83 & 0.88 & 1.00 & 1.08 & 1.10 & 0.95 \\
\hline & $(0.02)$ & $(0.02)$ & $(0.02)$ & $(0.02)$ & $(0.02)$ & $(0.02)$ & $(0.02)$ & $(0.02)$ & $(0.02)$ \\
\hline \multirow[t]{2}{*}{ landlocked } & -0.19 & -0.19 & -0.43 & -0.50 & -0.65 & -0.74 & -0.94 & -1.13 & -0.91 \\
\hline & $(0.06)$ & $(0.05)$ & $(0.06)$ & $(0.06)$ & $(0.06)$ & $(0.06)$ & $(0.06)$ & $(0.05)$ & $(0.04)$ \\
\hline \multirow[t]{2}{*}{ island } & 0.38 & 0.42 & 0.27 & 0.19 & 0.10 & 0.29 & 0.14 & 0.20 & 0.46 \\
\hline & $(0.05)$ & $(0.05)$ & $(0.06)$ & $(0.06)$ & $(0.05)$ & $(0.06)$ & $(0.06)$ & $(0.05)$ & $(0.05)$ \\
\hline \multirow[t]{2}{*}{ border } & 0.15 & 0.14 & 0.42 & -0.04 & 0.16 & 0.12 & 0.28 & 0.79 & 0.80 \\
\hline & $(0.13)$ & $(0.12)$ & $(0.13)$ & $(0.14)$ & $(0.14)$ & $(0.14)$ & $(0.14)$ & $(0.13)$ & $(0.11)$ \\
\hline \multirow[t]{2}{*}{ common language } & 0.41 & 0.45 & 0.45 & 0.44 & 0.33 & 0.34 & 0.30 & 0.52 & 0.55 \\
\hline & $(0.06)$ & $(0.05)$ & $(0.06)$ & $(0.06)$ & $(0.06)$ & $(0.07)$ & $(0.07)$ & $(0.06)$ & $(0.05)$ \\
\hline \multirow[t]{2}{*}{ constant } & -6.33 & -6.25 & -10.11 & -8.22 & -8.25 & -9.70 & -11.34 & -12.52 & -9.27 \\
\hline & $(0.46)$ & $(0.42)$ & $(0.44)$ & $(0.43)$ & $(0.40)$ & $(0.45)$ & $(0.47)$ & $(0.39)$ & $(0.32)$ \\
\hline Number of obs & 4477 & 5699 & 8040 & 8817 & 9657 & 10051 & 10842 & 13005 & 11942 \\
\hline R-squared & 0.44 & 0.43 & 0.35 & 0.33 & 0.34 & 0.31 & 0.33 & 0.36 & 0.46 \\
\hline
\end{tabular}

Notes: Dependent variable in the "Gravity Eqaution" is the log of total bilateral trade divided by GDP. See the text for precise definitions. 
Table 2: Gravity Equation Results, 1870-1939

\begin{tabular}{l|cccccc}
\hline Regressors & \multicolumn{5}{c}{ Year } \\
& 1920 & 1925 & 1928 & 1932 & 1935 & 1938 \\
\hline distance & -0.61 & -0.34 & -0.51 & -0.51 & -0.42 & -0.48 \\
& $(0.10)$ & $(0.07)$ & $(0.08)$ & $(0.07)$ & $(0.06)$ & $(0.06)$ \\
In (area) country i & 0.22 & 0.09 & -0.01 & -0.02 & -0.00 & 0.02 \\
& $(0.05)$ & $(0.04)$ & $(0.04)$ & $(0.04)$ & $(0.03)$ & $(0.03)$ \\
In (area) country j & 0.07 & -0.06 & -0.04 & -0.06 & -0.04 & -0.02 \\
& $(0.06)$ & $(0.04)$ & $(0.05)$ & $(0.04)$ & $(0.03)$ & $(0.04)$ \\
In (population) country i & -0.52 & -0.49 & -0.35 & -0.35 & -0.48 & -0.51 \\
& $(0.07)$ & $(0.05)$ & $(0.06)$ & $(0.05)$ & $(0.04)$ & $(0.05)$ \\
In (population) country j & 0.49 & 0.54 & 0.66 & 0.65 & 0.51 & 0.52 \\
& $(0.08)$ & $(0.06)$ & $(0.06)$ & $(0.05)$ & $(0.04)$ & $(0.05)$ \\
landlocked & -0.23 & -0.27 & -0.22 & -0.16 & -0.18 & -0.32 \\
& $(0.19)$ & $(0.12)$ & $(0.14)$ & $(0.12)$ & $(0.09)$ & $(0.12)$ \\
island & 0.70 & 0.41 & 0.00 & 0.04 & 0.48 & 0.50 \\
& $(0.16)$ & $(0.12)$ & $(0.13)$ & $(0.12)$ & $(0.09)$ & $(0.10)$ \\
border & 0.37 & 0.61 & 0.10 & 0.03 & 0.21 & -0.11 \\
& $(0.30)$ & $(0.19)$ & $(0.22)$ & $(0.19)$ & $(0.15)$ & $(0.19)$ \\
common language & 0.99 & 0.90 & 1.21 & 1.24 & 1.14 & 1.01 \\
& $(0.25)$ & $(0.18)$ & $(0.22)$ & $(0.20)$ & $(0.16)$ & $(0.18)$ \\
constant & -2.18 & -3.77 & -4.89 & -5.29 & -3.00 & -2.67 \\
& $(1.23)$ & $(0.88)$ & $(0.99)$ & $(0.86)$ & $(0.70)$ & $(0.80)$ \\
\hline Number of obs & 396 & 488 & 640 & 716 & 693 & 698 \\
R-squared & 0.38 & 0.43 & 0.36 & 0.38 & 0.48 & 0.42 \\
\hline \hline Notes: Dependent variable in the "Gravity Eqaution" is the log of total bilateral trade divided by GDP. See the
\end{tabular}

text for precise definitions.

\begin{tabular}{|c|c|c|c|c|c|c|c|c|c|}
\hline \multirow[t]{2}{*}{ Regressors } & \multicolumn{9}{|c|}{ Year } \\
\hline & 1870 & 1875 & 1880 & 1885 & 1890 & 1895 & 1900 & 1905 & 1910 \\
\hline \multirow[t]{2}{*}{ distance } & -0.46 & -0.50 & -1.04 & -1.00 & -1.02 & -0.93 & -0.78 & -0.67 & -0.71 \\
\hline & $(0.18)$ & $(0.14)$ & $(0.15)$ & $(0.16)$ & $(0.14)$ & $(0.12)$ & $(0.12)$ & $(0.12)$ & $(0.10)$ \\
\hline \multirow{2}{*}{ In (area) country $\mathrm{i}$} & 0.06 & 0.01 & 0.16 & 0.14 & 0.11 & 0.09 & 0.05 & -0.09 & -0.02 \\
\hline & $(0.08)$ & $(0.07)$ & $(0.08)$ & $(0.08)$ & $(0.07)$ & $(0.06)$ & $(0.07)$ & $(0.06)$ & $(0.05)$ \\
\hline \multirow[t]{2}{*}{ In (area) country j } & 0.03 & 0.05 & 0.10 & 0.07 & 0.09 & 0.12 & -0.07 & -0.13 & -0.03 \\
\hline & $(0.09)$ & $(0.07)$ & $(0.08)$ & $(0.09)$ & $(0.08)$ & $(0.07)$ & $(0.07)$ & $(0.06)$ & $(0.05)$ \\
\hline \multirow[t]{2}{*}{ In (population) country $\mathrm{i}$} & -0.43 & -0.32 & -0.24 & -0.27 & -0.33 & -0.24 & -0.21 & -0.11 & -0.17 \\
\hline & $(0.13)$ & $(0.10)$ & $(0.12)$ & $(0.12)$ & $(0.11)$ & $(0.09)$ & $(0.10)$ & $(0.08)$ & $(0.07)$ \\
\hline \multirow[t]{2}{*}{ In (population) country j } & 0.45 & 0.47 & 0.53 & 0.48 & 0.48 & 0.53 & 0.74 & 0.77 & 0.73 \\
\hline & $(0.10)$ & $(0.09)$ & $(0.11)$ & $(0.11)$ & $(0.09)$ & $(0.08)$ & $(0.08)$ & $(0.07)$ & $(0.06)$ \\
\hline \multirow[t]{2}{*}{ landlocked } & -0.97 & -1.33 & -1.41 & -1.05 & -0.77 & -0.66 & -0.65 & -0.84 & -0.41 \\
\hline & $(0.45)$ & $(0.34)$ & $(0.43)$ & $(0.42)$ & $(0.34)$ & $(0.26)$ & $(0.25)$ & $(0.26)$ & $(0.22)$ \\
\hline \multirow[t]{2}{*}{ island } & 1.43 & 1.25 & 0.17 & -0.21 & 0.12 & 0.41 & -0.18 & 0.07 & 0.40 \\
\hline & $(0.27)$ & $(0.23)$ & $(0.29)$ & $(0.29)$ & $(0.25)$ & $(0.23)$ & $(0.24)$ & $(0.19)$ & $(0.16)$ \\
\hline \multirow[t]{2}{*}{ border } & 1.29 & 1.91 & 0.73 & 0.45 & 0.48 & 0.59 & 0.68 & 0.89 & 0.53 \\
\hline & $(0.40)$ & $(0.32)$ & $(0.42)$ & $(0.42)$ & $(0.37)$ & $(0.33)$ & $(0.35)$ & $(0.36)$ & $(0.30)$ \\
\hline \multirow[t]{2}{*}{ common language } & 1.36 & 0.80 & 1.19 & 0.82 & 0.76 & 0.79 & 0.53 & 0.65 & 1.01 \\
\hline & $(0.44)$ & $(0.32)$ & $(0.43)$ & $(0.44)$ & $(0.38)$ & $(0.33)$ & $(0.34)$ & $(0.32)$ & $(0.28)$ \\
\hline \multirow[t]{2}{*}{ constant } & -3.33 & -3.13 & -1.64 & -0.87 & -0.57 & -1.93 & -0.80 & 0.36 & -1.05 \\
\hline & $(1.13)$ & $(0.93)$ & $(1.17)$ & $(1.21)$ & $(1.07)$ & $(0.91)$ & $(0.95)$ & $(0.89)$ & $(0.78)$ \\
\hline Number of obs & 173 & 245 & 290 & 293 & 330 & 386 & 416 & 481 & 451 \\
\hline R-squared & 0.50 & 0.52 & 0.37 & 0.34 & 0.40 & 0.42 & 0.41 & 0.39 & 0.49 \\
\hline
\end{tabular}

Notes: Dependent variable in the "Gravity Eqaution" is the log of total bilateral trade divided by GDP. See the text for precise definitions. 
Table 3: First Stage Regression Results, 1870-2000

\begin{tabular}{l|ccccccccc}
\hline Regressors & \multicolumn{7}{|c}{ Year } & \multicolumn{7}{c}{ } \\
& 1960 & 1965 & 1970 & 1975 & 1980 & 1985 & 1990 & 1995 & 2000 \\
\hline Predicted Openness & 2.28 & 2.35 & 3.73 & 4.6 & 5.06 & 3.88 & 3.93 & 3.49 & 3.51 \\
& $(0.43)$ & $(0.46)$ & $(0.76)$ & $(1.20)$ & $(1.52)$ & $(1.24)$ & $(1.51)$ & $(1.54)$ & $(0.79)$ \\
constant & 4.56 & 5.06 & 3.7 & 2.18 & -0.29 & 3.1 & 4.3 & 6.58 & 0.9 \\
& $(1.84)$ & $(1.94)$ & $(2.70)$ & $(5.91)$ & $(9.19)$ & $(5.25)$ & $(7.18)$ & $(8.99)$ & $(5.29)$ \\
\hline Number of obs & 76 & 90 & 97 & 103 & 104 & 105 & 105 & 117 & 115 \\
R-squared & 0.58 & 0.48 & 0.47 & 0.4 & 0.44 & 0.42 & 0.29 & 0.26 & 0.4 \\
\hline
\end{tabular}

NOTES: Dependent variable is the real value of total exports and imports divided by PPP-adjusted GDP. Predicted openness comes from the predicted values of the gravity equation presented in Table 1. Heteroscedasticity consistent errors are reported in parentheses.

\begin{tabular}{l|cccccc}
\hline \hline Regressors & \multicolumn{6}{|c}{ Year } \\
& 1920 & 1925 & 1928 & 1932 & 1935 & 1938 \\
\hline Predicted Openness & 0.83 & 1.01 & 0.84 & 1.08 & 1.06 & 0.95 \\
& $(0.22)$ & $(0.12)$ & $(0.28)$ & $(0.25)$ & $(0.12)$ & $(0.25)$ \\
constant & 15.20 & 7.92 & 15.06 & 5.77 & 5.25 & 8.10 \\
& $(4.88)$ & $(2.65)$ & $(3.46)$ & $(1.92)$ & $(1.60)$ & $(2.51)$ \\
\hline Number of obs & 22 & 26 & 27 & 29 & 29 & 29 \\
R-squared & 0.37 & 0.61 & 0.22 & 0.36 & 0.66 & 0.57 \\
\hline \hline
\end{tabular}

NOTES: Dependent variable is real value of total exports and imports divided by PPP-

adjusted GDP. Predicted openness comes from the predicted values of the gravity equation presented in Table 2. Heteroscedasticity consistent errors are reported in parentheses.

\begin{tabular}{l|ccccccccc}
\hline \hline Regressors & \multicolumn{10}{|c}{ Year } \\
& 1870 & 1875 & 1880 & 1885 & 1890 & 1895 & 1900 & 1905 & 1910 \\
\hline Predicted Openness & 0.95 & 0.98 & 0.86 & 1.16 & 1.15 & 1.52 & 1.36 & 1.16 & 1.18 \\
& $(0.39)$ & $(0.37)$ & $(0.23)$ & $(0.34)$ & $(0.30)$ & $(0.29)$ & $(0.29)$ & $(0.25)$ & $(0.28)$ \\
constant & 13.40 & 15.35 & 20.11 & 17.15 & 17.41 & 11.78 & 12.93 & 17.62 & 9.77 \\
& $(8.42)$ & $(10.12)$ & $(7.76)$ & $(7.71)$ & $(8.25)$ & $(7.01)$ & $(5.62)$ & $(5.31)$ & $(6.49)$ \\
\hline Number of obs & 18 & 19 & 17 & 19 & 19 & 21 & 21 & 22 & 23 \\
R-squared & 0.34 & 0.32 & 0.24 & 0.20 & 0.28 & 0.35 & 0.47 & 0.48 & 0.62 \\
\hline \hline
\end{tabular}

NOTES: Dependent variable is total exports and imports divided by GDP. Predicted openness comes from the predicted values of the gravity equation presented in Table 1. Heteroscedasticity consistent errors are reported in parentheses. 
Table 4: First Stage Regression Results for Pooled Data, 1870-2000

\begin{tabular}{l|cccc}
\hline Variable & Random Effects & Partial Adjustment & $\begin{array}{c}\text { Random Effects } \\
\text { Omitted Variables }\end{array}$ & Fixed Effects \\
& $(1)$ & $(2)$ & $(3)$ & $(4)$ \\
\hline Predicted Openness & 3.65 & 3.53 & 3.57 & 1.68 \\
& $(0.10)$ & $(0.11)$ & $(0.13)$ & $(0.13)$ \\
In(population) & --- & --- & -3.68 & --- \\
& & & $(0.35)$ & -- \\
In (land area) & --- & --- & 1.01 & -- \\
& & & $(0.36)$ & -6.4 \\
Polity t-1 & --- & 0.34 & -- & $(13.28)$ \\
& & $(0.06)$ & & 4184 \\
Constant & -2.26 & -2.29 & 43.45 & 0.83 \\
& $(3.08)$ & $(3.04)$ & $(5.55)$ & 4184 \\
\hline Number of obs & 4184 & 4084 & 0.43 & \\
R-Squared & 0.40 & 0.41 &
\end{tabular}

Notes: Sample is 1960 to 2000 . Dependent variable in all columns is real openness. Time dummies are not reported. Auto-correlation and heteroscedasticity consistent standard errors are reported in parentheses.

\begin{tabular}{|c|c|c|c|c|}
\hline$\overline{\text { Variable }}$ & $\begin{array}{c}\text { Random Effects } \\
\text { (1) }\end{array}$ & $\begin{array}{c}\text { Partial Adjustment } \\
\text { (2) }\end{array}$ & $\begin{array}{c}\text { Random Effects } \\
\text { Omitted Variables } \\
\text { (3) }\end{array}$ & $\begin{array}{c}\text { Fixed Effects } \\
\text { (4) }\end{array}$ \\
\hline Predicted Openness & $\begin{array}{c}0.88 \\
{[0.06]}\end{array}$ & $\begin{array}{c}0.68 \\
{[0.06]}\end{array}$ & $\begin{array}{c}0.58 \\
{[0.08]}\end{array}$ & $\begin{array}{c}0.23 \\
{[0.04]}\end{array}$ \\
\hline In(population) & --- & --- & $\begin{array}{c}0.54 \\
{[0.30]}\end{array}$ & --- \\
\hline In (land area) & --- & --- & $\begin{array}{l}-3.73 \\
{[0.61]}\end{array}$ & --- \\
\hline Polity $t-1$ & --- & $\begin{array}{c}0.66 \\
{[0.07]}\end{array}$ & --- & \\
\hline Constant & $\begin{array}{l}13.97 \\
{[2.69]}\end{array}$ & $\begin{array}{l}15.53 \\
{[2.41]}\end{array}$ & $\begin{array}{c}74.56 \\
{[13.31]}\end{array}$ & $\begin{array}{l}14.35 \\
{[1.45]}\end{array}$ \\
\hline $\begin{array}{l}\text { Number of obs } \\
\text { R-Squared }\end{array}$ & $\begin{array}{l}522 \\
0.50\end{array}$ & $\begin{array}{l}518 \\
0.62\end{array}$ & $\begin{array}{l}522 \\
0.57\end{array}$ & $\begin{array}{l}522 \\
0.9\end{array}$ \\
\hline
\end{tabular}

Notes: Sample is 1920 to 1940 . Dependent variable in all columns is real openness. Time dummies are not reported. Auto-correlation and heteroscedasticity consistent standard errors are reported in parentheses.

\begin{tabular}{|c|c|c|c|c|}
\hline Variable & $\begin{array}{c}\text { Random Effects } \\
\text { (1) } \\
\end{array}$ & $\begin{array}{c}\text { Partial Adjustment } \\
\text { (2) } \\
\end{array}$ & $\begin{array}{l}\text { Random Effects } \\
\text { Omitted Variables } \\
\text { (3) } \\
\end{array}$ & $\begin{array}{l}\text { Fixed Effects } \\
\text { (4) } \\
\end{array}$ \\
\hline Predicted Openness & $\begin{array}{c}1.76 \\
(0.24)\end{array}$ & $\begin{array}{c}1.35 \\
(0.36)\end{array}$ & $\begin{array}{c}1.9 \\
(0.28)\end{array}$ & $\begin{array}{c}0.35 \\
(0.30)\end{array}$ \\
\hline In(population) & --- & --- & $\begin{array}{l}-2.32 \\
(3.23)\end{array}$ & --- \\
\hline In (land area) & -- & --- & $\begin{array}{l}-6.26 \\
(4.99)\end{array}$ & --- \\
\hline Polity $t-1$ & --- & $\begin{array}{l}0.001 \\
(0.56)\end{array}$ & --- & \\
\hline Constant & $\begin{array}{c}-8.91 \\
(10.07) \\
\end{array}$ & $\begin{array}{r}138.89 \\
(94.63) \\
\end{array}$ & $\begin{array}{c}-8.97 \\
(12.56) \\
\end{array}$ & $\begin{array}{r}32.58 \\
(10.59) \\
\end{array}$ \\
\hline $\begin{array}{l}\text { Number of obs } \\
\text { R-Squared }\end{array}$ & $\begin{array}{l}190 \\
0.31\end{array}$ & $\begin{array}{l}170 \\
0.32\end{array}$ & $\begin{array}{l}190 \\
0.33 \\
\end{array}$ & $\begin{array}{l}190 \\
0.79\end{array}$ \\
\hline
\end{tabular}

Notes: Sample is 1870 to 1910 with country year observations every five years. Dependent variable in all columns is real openness. Time dummies are not reported. Auto-correlation and heteroscedasticity consistent standard errors are reported in parentheses. 
Table 5: Openness and Democracy: Panel Estimates for Three Periods

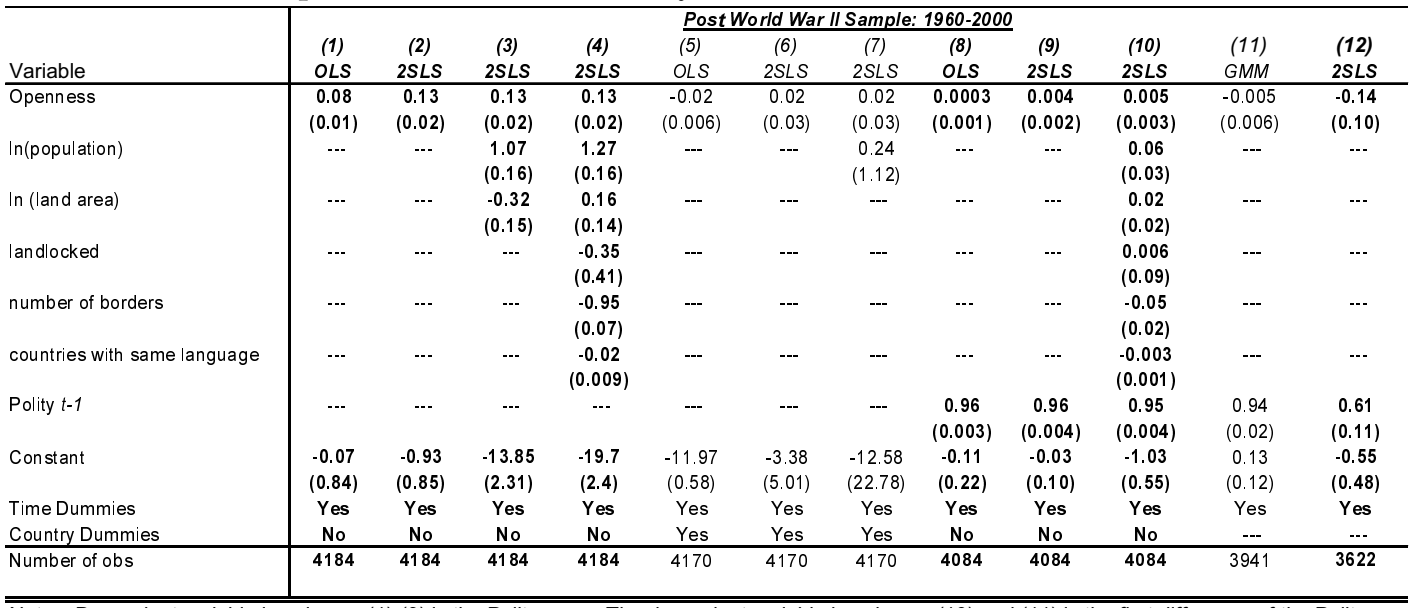

Notes: Dependent variable in columns (1)-(9) is the Polity score. The dependent variable in columns (10) and (11) is the first difference of the Polity score. Auto-correlation and heteroscedasticity consistent standard errors are reported in parentheses in columns (1)-(9). Heteroscedasticity consistent standard errors are reported in parentheses in columns (10) and (11). Time dummies are not reported.

\begin{tabular}{|c|c|c|c|c|c|c|c|c|c|c|c|c|}
\hline \multirow[b]{3}{*}{ Variable } & \multicolumn{12}{|c|}{ Interwar Sample: 1920-1940 } \\
\hline & (1) & (2) & (3) & (4) & (5) & (6) & (7) & (8) & (9) & (10) & (11) & (12) \\
\hline & OLS & $2 S L S$ & $2 S L S$ & $2 S L S$ & OLS & $2 S L S$ & $2 S L S$ & OLS & $2 S L S$ & $2 S L S$ & $G M M$ & $2 S L S$ \\
\hline Openness & 0.38 & 0.40 & 0.58 & 0.57 & 0.01 & -0.12 & -0.15 & 0.02 & 0.02 & 0.05 & 0.03 & 0.48 \\
\hline & $(0.03)$ & $(0.04)$ & $(0.09)$ & $(0.09)$ & $(0.02)$ & $(0.08)$ & $(0.09)$ & $(0.01)$ & $(0.01)$ & $(0.03)$ & $(0.02)$ & (1.44) \\
\hline $\operatorname{In}$ (population) & --- & --- & 1.96 & 2.00 & - & - & -6.17 & -- & --- & 0.24 & - & --- \\
\hline & & & $(0.78)$ & $(0.67)$ & & & $(6.04)$ & & & $(0.16)$ & & \\
\hline In (land area) & -- & -- & -0.20 & -0.08 & -- & - & - & -- & --- & -0.001 & - & --- \\
\hline & & & $(0.2)$ & $(0.21)$ & & & & & & $(0.04)$ & & \\
\hline landlocked & -- & --- & --- & $\begin{array}{c}3.32 \\
(0.93)\end{array}$ & - & - & - & -- & --- & $\begin{array}{c}0.46 \\
(0.29)\end{array}$ & - & --- \\
\hline number of borders & --- & --- & --- & $\begin{array}{c}-0.11 \\
(0.25)\end{array}$ & - & - & - & -- & --- & $\begin{array}{c}-0.06 \\
(0.07)\end{array}$ & - & -- \\
\hline countries with same language & - & - & - & $\begin{array}{l}0.06 \\
(0.1)\end{array}$ & - & - & - & -- & --- & $\begin{array}{c}0.02 \\
(0.03)\end{array}$ & - & --- \\
\hline Polity $t-1$ & -- & -- & --- & --- & - & - & - & $\begin{array}{c}0.98 \\
(0.01)\end{array}$ & $\begin{array}{c}0.97 \\
(0.02)\end{array}$ & $\begin{array}{c}0.95 \\
(0.02)\end{array}$ & $\begin{array}{c}0.77 \\
(0.08)\end{array}$ & $\begin{array}{c}0.02 \\
(1.17)\end{array}$ \\
\hline Constant & $\begin{array}{l}-5.46 \\
(1.42)\end{array}$ & $\begin{array}{c}-6.25 \\
(1.82)\end{array}$ & $\begin{array}{c}-43.09 \\
(14.82)\end{array}$ & $\begin{array}{r}-45.46 \\
(13.80)\end{array}$ & $\begin{array}{l}10.08 \\
(0.47)\end{array}$ & $\begin{array}{l}13.24 \\
(1.55)\end{array}$ & $\begin{array}{l}128.05 \\
(112.1)\end{array}$ & $\begin{array}{c}0.16 \\
(0.45)\end{array}$ & $\begin{array}{l}0.09 \\
(.41)\end{array}$ & $\begin{array}{c}-4.86 \\
(3.55)\end{array}$ & $\begin{array}{l}-0.03 \\
(0.03)\end{array}$ & $\begin{array}{c}5.35 \\
(15.8)\end{array}$ \\
\hline Time Dummies & Yes & Yes & Yes & Yes & Yes & Yes & Yes & Yes & Yes & Yes & Yes & Yes \\
\hline Country Dummies & No & No & No & No & Yes & Yes & Yes & No & No & No & - & -- \\
\hline Number of obs & 522 & 522 & 522 & 522 & 522 & 518 & 522 & 518 & 518 & 518 & 481 & 466 \\
\hline
\end{tabular}

Notes: Dependent variable in columns (1)-(9) is the Polity score. The dependent variable in columns (10) and (11) is the first difference of the Polity score. Auto-correlation and heteroscedasticity consistent standard errors are reported in parentheses in columns (1)-(9). Heteroscedasticity consistent standard errors are reported in parentheses in columns (10) and (11). Time dummies are not reported. 
Table 6: Openness and Democracy: Panel Estimates for Three Periods (cont.)

\begin{tabular}{|c|c|c|c|c|c|c|c|c|c|c|c|c|}
\hline \multirow[b]{3}{*}{ Variable } & \multicolumn{12}{|c|}{ Pre-World War I Sample: 1870-1910 } \\
\hline & (1) & (2) & (3) & (4) & (5) & (6) & (7) & (8) & (9) & (10) & (11) & (12) \\
\hline & OLS & $2 S L S$ & $2 S L S$ & $2 S L S$ & OLS & $2 S L S$ & $2 S L S$ & OLS & $2 S L S$ & $2 S L S$ & GMM & $2 S L S$ \\
\hline Openness & 0.02 & 0.07 & 0.10 & 0.16 & 0.0005 & -0.14 & -0.17 & -0.002 & 0.006 & 0.00 & 0.02 & 0.13 \\
\hline & $(0.01)$ & $(0.03)$ & $(0.06)$ & $(0.07)$ & $(0.01)$ & $(0.15)$ & $(0.16)$ & $(0.003)$ & $(0.006)$ & $(0.007)$ & $(0.02)$ & $(0.08)$ \\
\hline $\ln$ (population) & --- & --- & $\begin{array}{c}0.48 \\
(1.22)\end{array}$ & $\begin{array}{c}3.1 \\
(1.22)\end{array}$ & -- & - & $\begin{array}{l}-4.15 \\
(6.29)\end{array}$ & --- & --- & $\begin{array}{c}-0.03 \\
(0.22)\end{array}$ & - & - \\
\hline In (land area) & --- & --- & $\begin{array}{c}0.44 \\
(0.77)\end{array}$ & $\begin{array}{c}0.81 \\
(0.77)\end{array}$ & -- & - & - & --- & -- & $\begin{array}{c}-0.11 \\
(0.13)\end{array}$ & - & - \\
\hline landlocked & --- & --- & --- & $\begin{array}{c}3.45 \\
(2.57)\end{array}$ & - & - & - & --- & --- & $\begin{array}{c}-0.53 \\
(0.27)\end{array}$ & - & - \\
\hline number of borders & --- & --- & --- & $\begin{array}{l}-1.53 \\
(0.3)\end{array}$ & - & - & - & --- & -- & $\begin{array}{c}-0.02 \\
(0.07)\end{array}$ & - & - \\
\hline countries with same language & --- & --- & --- & $\begin{array}{c}0.07 \\
(0.23)\end{array}$ & -- & - & - & --- & --- & $\begin{array}{c}-0.01 \\
(0.03)\end{array}$ & - & - \\
\hline Polity $t-5$ & -- & --- & -- & -- & - & - & - & $\begin{array}{c}0.96 \\
(0.02)\end{array}$ & $\begin{array}{c}0.95 \\
(0.02)\end{array}$ & $\begin{array}{c}0.96 \\
(0.02)\end{array}$ & $\begin{array}{c}0.66 \\
(0.06)\end{array}$ & $\begin{array}{l}0.62 \\
(0.4)\end{array}$ \\
\hline Constant & $\begin{array}{c}0.37 \\
(0.89)\end{array}$ & $\begin{array}{c}-3.12 \\
(1.79)\end{array}$ & $\begin{array}{l}-18.49 \\
(27.77)\end{array}$ & $\begin{array}{c}-64.9 \\
(28.68)\end{array}$ & $\begin{array}{c}3.96 \\
(0.86)\end{array}$ & $\begin{array}{c}9.27 \\
(5.84)\end{array}$ & $\begin{array}{c}81.99 \\
(106.92)\end{array}$ & $\begin{array}{c}0.67 \\
(0.19)\end{array}$ & $\begin{array}{c}0.29 \\
(0.30)\end{array}$ & $\begin{array}{c}2.54 \\
(4.11)\end{array}$ & $\begin{array}{c}0.2 \\
(0.1)\end{array}$ & $\begin{array}{c}0.29 \\
(0.26)\end{array}$ \\
\hline Time Dummies & Yes & Yes & Yes & Yes & Yes & Yes & Yes & Yes & Yes & Yes & Yes & Yes \\
\hline Country Dummies & No & No & No & No & Yes & Yes & Yes & No & No & No & - & \\
\hline Number of Obs & 190 & 190 & 190 & 190 & 190 & 190 & 190 & 170 & 170 & 170 & 147 & 108 \\
\hline
\end{tabular}

Nes: Dependent variable in columns (1)-(9) is the Polity score. The dependent variable in columns (10) and (11) is the first difference of the Polity score which for this sample is recorded each five years. Auto-correlation and heteroscedasticity consistent standard errors are reported in parentheses in columns (1)-(9). Heteroscedasticity consistent standard errors are reported in parentheses in columns (10) and (11). Time dummies are not reported. For this Pre-World War I sample, the observations are for country years every five years beginning in 1870 . 
Table 7: Instrumental Variables Estimations with Omitted Variables and Regional Coefficients, 1960-2000

\begin{tabular}{|c|c|c|c|c|c|c|c|}
\hline \multirow[t]{2}{*}{ Variable } & \multirow[b]{2}{*}{ (1) } & \multirow[b]{2}{*}{ (2) } & \multirow[t]{2}{*}{ Variable } & \multicolumn{4}{|c|}{ Regional Variation in Coefficients } \\
\hline & & & & (3) & (4) & (5) & (6) \\
\hline Openness & $\begin{array}{c}0.06 \\
(0.01)\end{array}$ & $\begin{array}{c}-0.01 \\
(0.01)\end{array}$ & East Asia Pacific $\times$ Openness & $\begin{array}{c}0.04 \\
(0.01)\end{array}$ & $\begin{array}{c}0.01 \\
(0.01)\end{array}$ & $\begin{array}{c}0.001 \\
(0.002)\end{array}$ & $\begin{array}{l}0.0006 \\
(0.002)\end{array}$ \\
\hline In (population) & -- & $\begin{array}{c}-0.19 \\
(0.13)\end{array}$ & Eastern Europe/CIS $\times$ Openness & $\begin{array}{c}0.13 \\
(0.03)\end{array}$ & $\begin{array}{c}0.07 \\
(0.04)\end{array}$ & $\begin{array}{c}0.01 \\
(0.01)\end{array}$ & $\begin{array}{c}0.01 \\
(0.01)\end{array}$ \\
\hline In (land area) & --- & $\begin{array}{c}-0.75 \\
(0.12)\end{array}$ & Middle East/North Africa $\times$ Openness & $\begin{array}{c}-0.13 \\
(0.02)\end{array}$ & $\begin{array}{c}-0.17 \\
(0.03)\end{array}$ & $\begin{array}{c}-0.01 \\
(0.01)\end{array}$ & $\begin{array}{l}-0.01 \\
(0.01)\end{array}$ \\
\hline Distance from Equator & $\begin{array}{c}0.15 \\
(0.02)\end{array}$ & $\begin{array}{c}0.18 \\
(0.02)\end{array}$ & South Asia $x$ Openness & $\begin{array}{c}0.4 \\
(0.10)\end{array}$ & $\begin{array}{c}0.2 \\
(0.11)\end{array}$ & $\begin{array}{l}-0.004 \\
(0.02)\end{array}$ & $\begin{array}{l}-0.01 \\
(0.03)\end{array}$ \\
\hline Ethnolinguistic Fragmentation & $\begin{array}{c}3.76 \\
(0.58)\end{array}$ & $\begin{array}{c}5.5 \\
(0.61)\end{array}$ & Western Europe $x$ Openness & $\begin{array}{c}0.19 \\
(0.01)\end{array}$ & $\begin{array}{c}0.17 \\
(0.01)\end{array}$ & $\begin{array}{c}0.01 \\
(0.002)\end{array}$ & $\begin{array}{c}0.01 \\
(0.003)\end{array}$ \\
\hline Primary Commodity Exporter Dummy & $\begin{array}{l}-2.04 \\
(0.31)\end{array}$ & $\begin{array}{l}-1.81 \\
(0.32)\end{array}$ & Sub-Saharan Africa $\times$ Openness & $\begin{array}{c}-0.12 \\
(0.02)\end{array}$ & $\begin{array}{l}-0.16 \\
(0.03)\end{array}$ & $\begin{array}{l}-0.01 \\
(0.01)\end{array}$ & $\begin{array}{c}-0.01 \\
(0.01)\end{array}$ \\
\hline Petroleum Exporter Dummy & $\begin{array}{l}-1.08 \\
(0.50)\end{array}$ & $\begin{array}{c}0.36 \\
(0.53)\end{array}$ & Latin America/Caribbean $\times$ Openness & $\begin{array}{c}0.14 \\
(0.02)\end{array}$ & $\begin{array}{c}0.09 \\
(0.02)\end{array}$ & $\begin{array}{c}0.01 \\
(0.004)\end{array}$ & $\begin{array}{c}0.01 \\
(0.01)\end{array}$ \\
\hline East Asia Pacific & $\begin{array}{c}-3.71 \\
(0.96)\end{array}$ & $\begin{array}{l}-5.21 \\
(0.95)\end{array}$ & USA/Canada x Openness & $\begin{array}{c}0.34 \\
(0.03)\end{array}$ & $\begin{array}{c}0.35 \\
(0.03)\end{array}$ & $\begin{array}{c}0.02 \\
(0.008)\end{array}$ & $\begin{array}{c}0.02 \\
(0.01)\end{array}$ \\
\hline Eastern Europe/CIS States & $\begin{array}{l}-7.99 \\
(0.98)\end{array}$ & $\begin{array}{r}-11.46 \\
(1.06)\end{array}$ & $\ln$ (population) & --- & $\begin{array}{c}0.37 \\
(0.16)\end{array}$ & --- & $\begin{array}{c}0.03 \\
(0.04)\end{array}$ \\
\hline Middle East/North Africa & $\begin{array}{r}-12.43 \\
(0.97)\end{array}$ & $\begin{array}{l}-15.22 \\
(1.02)\end{array}$ & In (land area) & -- & $\begin{array}{c}-0.52 \\
(0.12)\end{array}$ & --- & $\begin{array}{c}-0.02 \\
(0.03)\end{array}$ \\
\hline South Asia & $\begin{array}{c}-3 \\
(1.06)\end{array}$ & $\begin{array}{c}-6.25 \\
(1.14)\end{array}$ & Polity t-1 & --- & --- & $\begin{array}{c}0.94 \\
(0.01)\end{array}$ & $\begin{array}{c}0.94 \\
(0.01)\end{array}$ \\
\hline Western Europe & $\begin{array}{l}-2.12 \\
(0.93)\end{array}$ & $\begin{array}{l}-4.13 \\
(0.93)\end{array}$ & Constant & $\begin{array}{c}-0.23 \\
(0.99)\end{array}$ & $\begin{array}{c}1.12 \\
(3.21)\end{array}$ & $\begin{array}{c}0.02 \\
(0.21)\end{array}$ & $\begin{array}{l}-0.14 \\
(0.66)\end{array}$ \\
\hline Sub-Saharan Africa & $\begin{array}{l}-7.75 \\
(0.99)\end{array}$ & $\begin{array}{c}-11.22 \\
(1.09)\end{array}$ & & & & & \\
\hline Latin America/Carribean & $\begin{array}{l}-2.17 \\
(0.97)\end{array}$ & $\begin{array}{c}-5 \\
(1.03)\end{array}$ & & & & & \\
\hline Constant & $\begin{array}{c}-0.36 \\
(1.46)\end{array}$ & $\begin{array}{l}14.12 \\
(3.08)\end{array}$ & & & & & \\
\hline Number of obs & 4184 & 4184 & Number of obs & 4184 & 4184 & 4084 & 4084 \\
\hline
\end{tabular}

NOTES: Dependent variable is the Polity score. Estimations assume a "random effects" error term. Auto-correlation and

heteroscedasticity consistent standard errors are reported in parentheses in columns. Year indicators are not reported. Omitted category

in the regional dummies is "North America" which includes Canada and the US. 
Table 8: Democracy and Openness, OLS Regressions, 1870-2000

\begin{tabular}{l|ccccccccc}
\hline Regressors & \multicolumn{8}{|c}{ Year } & \multicolumn{1}{c}{ } \\
& 1960 & 1965 & 1970 & 1975 & 1980 & 1985 & 1990 & 1995 & 2000 \\
\hline Openness & 0.23 & 0.21 & 0.17 & 0.08 & 0.05 & 0.08 & 0.07 & 0.04 & 0.05 \\
& $(0.06)$ & $(0.05)$ & $(0.08)$ & $(0.04)$ & $(0.04)$ & $(0.06)$ & $(0.05)$ & $(0.03)$ & $(0.03)$ \\
constant & -2.5 & -3.56 & -3.49 & -2.99 & -2.13 & -1.56 & 0.4 & 3.2 & 3.37 \\
& $(1.28)$ & $(1.21)$ & $(1.45)$ & $(1.21)$ & $(1.35)$ & $(1.31)$ & $(1.31)$ & $(1.08)$ & $(1.00)$ \\
\hline Number of obs & 76 & 90 & 97 & 103 & 104 & 105 & 105 & 117 & 115 \\
R-squared & 0.15 & 0.13 & 0.11 & 0.05 & 0.05 & 0.05 & 0.06 & 0.04 & 0.08 \\
\hline
\end{tabular}

NOTES: Dependent variable is the Polity score as described in text. GDP in the openness variable is adjusted for purchasing power parity. Heteroscedasticity consistent errors are reported in parentheses.

\begin{tabular}{l|cccccc}
\hline \hline Regressors & \multicolumn{7}{|c}{ Year } \\
& 1920 & 1925 & 1928 & 1932 & 1935 & 1938 \\
\hline Openness & 0.14 & 0.36 & 0.39 & 0.58 & 0.51 & 0.46 \\
& $(0.04)$ & $(0.08)$ & $(0.08)$ & $(0.16)$ & $(0.11)$ & $(0.09)$ \\
constant & 2.24 & -4.37 & -5.41 & -3.88 & -6.89 & -6.28 \\
& $(1.81)$ & $(2.52)$ & $(2.58)$ & $(2.77)$ & $(2.89)$ & $(2.67)$ \\
\hline Number of obs & 22 & 26 & 27 & 29 & 29 & 29 \\
R-squared & 0.37 & 0.5 & 0.51 & 0.31 & 0.35 & 0.39 \\
\hline \hline
\end{tabular}

NOTES: Dependent variable is the Polity score as described in text. GDP in the

openness variable is adjusted for purchasing power parity. Heteroscedasticity consistent errors are reported in parentheses.

\begin{tabular}{l|ccccccccc}
\hline \hline Regressors & \multicolumn{1}{|c}{ Year } & \multicolumn{1}{c}{ } & & & \\
& 1870 & 1875 & 1880 & 1885 & 1890 & 1895 & 1900 & 1905 & 1910 \\
\hline Openness & 0.11 & 0.07 & 0.08 & 0.09 & 0.08 & 0.12 & 0.15 & 0.12 & 0.10 \\
& $(0.06)$ & $(0.07)$ & $(0.07)$ & $(0.05)$ & $(0.05)$ & $(0.06)$ & $(0.06)$ & $(0.05)$ & $(0.06)$ \\
constant & -5.11 & -3.03 & -2.77 & -2.59 & -1.77 & -3.36 & -3.82 & -1.74 & -0.06 \\
& $(2.75)$ & $(3.11)$ & $(3.28)$ & $(2.81)$ & $(2.74)$ & $(2.96)$ & $(3.10)$ & $(2.90)$ & $(2.84)$ \\
\hline Number of obs & 18 & 19 & 17 & 19 & 19 & 21 & 21 & 22 & 23 \\
R-squared & 0.19 & 0.08 & 0.07 & 0.13 & 0.12 & 0.17 & 0.23 & 0.16 & 0.16 \\
\hline \hline
\end{tabular}

NOTES: Dependent variable is the Polity score as described in text. GDP in the openness variable is adjusted for

purchasing power parity. Heteroscedasticity consistent errors are reported in parentheses. 
Table 9: Democracy and Openness, Instrumental Variables Regressions, 1870-2000

\begin{tabular}{|c|c|c|c|c|c|c|c|c|c|}
\hline \multirow[t]{2}{*}{ Regressors } & \multicolumn{8}{|c|}{ Year } & \multirow[b]{2}{*}{2000} \\
\hline & 1960 & 1965 & 1970 & 1975 & 1980 & 1985 & 1990 & 1995 & \\
\hline \multirow[t]{2}{*}{ Openness } & 0.28 & 0.24 & 0.25 & 0.18 & 0.11 & 0.15 & 0.13 & 0.06 & 0.04 \\
\hline & $(0.08)$ & $(0.08)$ & $(0.14)$ & $(0.09)$ & $(0.06)$ & $(0.10)$ & $(0.08)$ & $(0.06)$ & $(0.03)$ \\
\hline \multirow[t]{2}{*}{ constant } & -3.25 & -3.97 & -4.87 & -5.9 & -4.05 & -3.01 & -1.44 & 2.45 & 3.61 \\
\hline & (1.39) & (1.55) & (2.49) & $(2.32)$ & (1.99) & $(2.17)$ & (2.22) & (1.68) & (1.03) \\
\hline Number of obs & 76 & 90 & 97 & 103 & 104 & 105 & 105 & 117 & 115 \\
\hline R-squared & 0.14 & 0.13 & 0.09 & & 0 & 0.02 & & 0.02 & 0.08 \\
\hline
\end{tabular}

NOTES: Dependent variable is the polity score as described in text. Instrumental variable for openness is the value of predicted openness as described in the text. Heteroscedasticity consistent errors are reported in parentheses.

\begin{tabular}{l|cccccc}
\hline \hline Regressors & \multicolumn{7}{|c}{ Year } \\
& 1920 & 1925 & 1928 & 1932 & 1935 & 1938 \\
\hline Openness & 0.23 & 0.36 & 0.53 & 0.79 & 0.51 & 0.43 \\
& $(0.07)$ & $(0.11)$ & $(0.17)$ & $(0.23)$ & $(0.14)$ & $(0.10)$ \\
constant & -0.54 & -4.21 & -8.99 & -6.61 & -6.85 & -5.85 \\
& $(2.71)$ & $(3.13)$ & $(4.72)$ & $(3.99)$ & $(3.30)$ & $(2.84)$ \\
\hline Number of obs & 22 & 26 & 27 & 29 & 29 & 29 \\
R-squared & 0.23 & 0.50 & 0.45 & 0.27 & 0.35 & 0.39 \\
\hline \hline
\end{tabular}

NOTES: Dependent variable is the polity score as described in text. Instrumental

variable for openness is the value of predicted openness as described in the text.

Heteroscedasticity consistent errors are reported in parentheses.

\begin{tabular}{l|ccccccccc}
\hline \hline Regressors & \multicolumn{10}{|c}{ Year } \\
& 1870 & 1875 & 1880 & 1885 & 1890 & 1895 & 1900 & 1905 & 1910 \\
\hline Openness & 0.22 & 0.15 & 0.17 & 0.12 & 0.12 & 0.18 & 0.16 & 0.11 & 0.14 \\
& $(0.11)$ & $(0.13)$ & $(0.13)$ & $(0.12)$ & $(0.10)$ & $(0.10)$ & $(0.09)$ & $(0.07)$ & $(0.07)$ \\
constant & -9.7 & -6.2 & -5.93 & -3.9 & -3.07 & -5.81 & -4.19 & -1.67 & -1.39 \\
& $(4.52)$ & $(5.56)$ & $(5.97)$ & $(5.64)$ & $(4.83)$ & $(4.58)$ & $(4.26)$ & $(3.71)$ & $(3.23)$ \\
\hline Number of obs & 18 & 19 & 17 & 19 & 19 & 21 & 21 & 22 & 23 \\
R-squared & --- & --- & -- & 0.11 & 0.11 & 0.12 & 0.23 & 0.16 & 0.14 \\
\hline \hline
\end{tabular}

NOTES: Dependent variable is the polity score as described in text. Instrumental variable for openness is the value of predicted openness as described in the text. Heteroscedasticity consistent errors are reported in parentheses. 
Table 10: Democracy and Openness, Instrumental Variables Regressions Controlling for Country Size, 1870-2000

\begin{tabular}{l|ccccccccc}
\hline Variable & 1960 & 1965 & 1970 & 1975 & 1980 & 1985 & 1990 & 1995 & 2000 \\
\hline Openness & 0.52 & 0.43 & 0.23 & 0.23 & 0.12 & 0.15 & 0.09 & 0.07 & 0.06 \\
& $(0.11)$ & $(0.11)$ & $(0.16)$ & $(0.10)$ & $(0.05)$ & $(0.09)$ & $(0.06)$ & $(0.05)$ & $(0.03)$ \\
Ln (population) & 2.16 & 2.91 & 1.4 & 1.51 & 1.08 & 0.9 & 1.15 & 0.2 & 0.3 \\
& $(0.70)$ & $(0.68)$ & $(0.84)$ & $(0.91)$ & $(0.77)$ & $(0.76)$ & $(0.70)$ & $(0.60)$ & $(0.60)$ \\
In (land area) & 0.54 & -0.91 & -0.64 & 0.01 & -0.21 & -0.16 & -0.64 & 0.08 & 0.1 \\
& $(0.82)$ & $(0.49)$ & $(0.61)$ & $(0.85)$ & $(0.79)$ & $(0.70)$ & $(0.73)$ & $(0.54)$ & $(0.54)$ \\
Constant & -48.07 & -41.94 & -18.96 & -31.51 & -19.07 & -15.71 & -11.06 & -1.82 & -2.98 \\
& $(13.13)$ & $(11.84)$ & $(14.35)$ & $(13.46)$ & $(9.51)$ & $(9.89)$ & $(8.91)$ & $(7.90)$ & $(7.31)$ \\
\hline Number of obs & 76 & 90 & 97 & 103 & 104 & 105 & 105 & 117 & 115 \\
R-squared & 0.18 & 0.21 & 0.15 & --- & 0.02 & 0.04 & 0.08 & 0.02 & 0.09 \\
\hline \hline
\end{tabular}

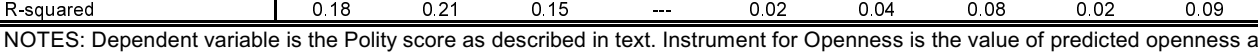
described in the text. Heteroscedasticity consistent standard errors are in parentheses.

\begin{tabular}{l|cccccc}
\hline \hline Regressors & \multicolumn{6}{|c}{ Year } \\
& 1920 & 1925 & 1928 & 1932 & 1935 & 1938 \\
\hline Openness & 0.69 & 0.63 & 1.3 & 0.91 & 0.81 & 0.87 \\
& $(0.52)$ & $(0.19)$ & $(0.87)$ & $(0.33)$ & $(0.28)$ & $(0.20)$ \\
Ln (population) & 5.72 & 2.85 & 7.74 & 1.18 & 2.71 & 3.52 \\
& $(6.28)$ & $(1.71)$ & $(7.38)$ & $(2.05)$ & $(2.74)$ & $(2.50)$ \\
In (land area) & -0.62 & -0.41 & -1.08 & -0.27 & -0.14 & 0.78 \\
& $(0.94)$ & $(0.58)$ & $(1.15)$ & $(0.83)$ & $(0.72)$ & $(0.68)$ \\
constant & -101.15 & -52.52 & -141.45 & -24.24 & -54.97 & -80.78 \\
& $(112.41)$ & $(31.83)$ & $(135.05)$ & $(37.97)$ & $(49.06)$ & $(42.62)$ \\
\hline Number of obs & 22 & 26 & 27 & 29 & 29 & 29 \\
R-squared & --- & 0.46 & --- & 0.23 & 0.35 & 0.4 \\
\hline \hline
\end{tabular}

NOTES: Dependent variable is the polity score as described in text. Instrumental variable for

openness is the value of predicted openness as described in the text. Heteroscedasticity consistent errors are reported in parentheses.

\begin{tabular}{|c|c|c|c|c|c|c|c|c|c|}
\hline \multirow[t]{2}{*}{ Regressors } & \multicolumn{9}{|c|}{ Year } \\
\hline & 1870 & 1875 & 1880 & 1885 & 1890 & 1895 & 1900 & 1905 & 1910 \\
\hline \multirow[t]{2}{*}{ Openness } & 0.48 & 0.44 & 0.16 & -0.01 & 0.07 & 0.17 & 0.05 & 0.01 & 0.07 \\
\hline & $(0.26)$ & $(0.51)$ & $(0.35)$ & $(0.18)$ & $(0.18)$ & $(0.17)$ & $(0.09)$ & $(0.06)$ & $(0.07)$ \\
\hline \multirow[t]{2}{*}{ Ln (population) } & 2.95 & 3.06 & 2.37 & -0.68 & 0.32 & 1.85 & -0.2 & -1.52 & -0.91 \\
\hline & (2.92) & $(3.83)$ & $(6.07)$ & $(4.34)$ & (3.57) & $(2.80)$ & $(2.64)$ & $(2.38)$ & $(2.18)$ \\
\hline \multirow[t]{2}{*}{ In (land area) } & 2.82 & 2.72 & 0.22 & -0.67 & 0.39 & 1.08 & -0.28 & -0.12 & 0.78 \\
\hline & $(2.03)$ & $(3.97)$ & $(2.45)$ & $(1.63)$ & $(2.30)$ & $(2.35)$ & $(1.84)$ & $(1.49)$ & (1.49) \\
\hline constant & $\begin{array}{l}-104.57 \\
(73.72)\end{array}$ & $\begin{array}{c}-103.49 \\
(127.39)\end{array}$ & $\begin{array}{c}-49.7 \\
(139.81)\end{array}$ & $\begin{array}{c}21.17 \\
(92.17)\end{array}$ & $\begin{array}{l}-12.23 \\
(88.15)\end{array}$ & $\begin{array}{l}-51.56 \\
(6904)\end{array}$ & $\begin{array}{c}6.78 \\
(5964)\end{array}$ & $\begin{array}{c}29.22 \\
(4880)\end{array}$ & 5.49 \\
\hline Number of obs & 18 & 19 & 20 & 21 & 21 & 22 & 22 & 23 & 24 \\
\hline R-squared & --- & --- & 0.02 & --. & -.- & -.- & 0.04 & --. & \\
\hline
\end{tabular}

NOTES: Dependent variable is the polity score as described in text. Instrumental variable for openness is the value of predicted openness as described in the text. Heteroscedasticity consistent errors are reported in parentheses. 
Table 11: Ordered Probit "Instrumental Variables" Regressions with Additional Controls, 19602000, 1920-1938

\begin{tabular}{|c|c|c|c|c|c|c|c|c|c|}
\hline \multirow[b]{2}{*}{ Variable } & \multicolumn{8}{|c|}{ Post World War II Sample: 1960-2000 } & \multirow[b]{2}{*}{2000} \\
\hline & 1960 & 1965 & 1970 & 1975 & 1980 & 1985 & 1990 & 1995 & \\
\hline \multirow[t]{2}{*}{ Openness } & 0.06 & 0.05 & 0.04 & 0.04 & 0.03 & 0.03 & 0.02 & 0.02 & 0.02 \\
\hline & $(0.02)$ & $(0.01)$ & $(0.03)$ & $(0.02)$ & $(0.01)$ & $(0.01)$ & $(0.01)$ & $(0.01)$ & $(0.01)$ \\
\hline \multirow[t]{2}{*}{ Openness Residuals } & -0.03 & -0.02 & -0.02 & -0.04 & -0.02 & -0.03 & -0.01 & -0.01 & -0.004 \\
\hline & $(0.02)$ & $(0.02)$ & $(0.02)$ & $(0.02)$ & $(0.01)$ & $(0.02)$ & $(0.01)$ & $(0.01)$ & $(0.01)$ \\
\hline \multirow{2}{*}{ In (Population) } & 0.34 & 0.41 & 0.2 & 0.15 & 0.12 & 0.12 & 0.1 & -0.03 & 0.002 \\
\hline & $(0.11)$ & $(0.11)$ & $(0.12)$ & $(0.09)$ & $(0.09)$ & $(0.09)$ & $(0.11)$ & $(0.12)$ & $(0.13)$ \\
\hline \multirow[t]{2}{*}{ In (land area) } & 0.05 & -0.15 & -0.06 & 0.04 & 0.01 & 0.02 & -0.02 & 0.06 & 0.08 \\
\hline & $(0.11)$ & $(0.08)$ & $(0.10)$ & $(0.11)$ & $(0.11)$ & $(0.11)$ & $(0.11)$ & $(0.09)$ & $(0.11)$ \\
\hline Cutpoint 1 & 5.04 & 3.13 & 0.61 & 1.86 & 0.41 & 1.44 & -0.11 & -1.63 & -0.35 \\
\hline Cutpoint 2 & 5.84 & 4.53 & 1.99 & 2.68 & 1.59 & 1.83 & 0.30 & -0.86 & 0.00 \\
\hline Cutpoint 3 & 6.08 & 4.61 & 2.15 & 2.94 & 1.87 & 2.60 & 1.25 & -0.48 & 0.12 \\
\hline Cutpoint 4 & 6.50 & 5.15 & 2.86 & 3.70 & 2.48 & 2.73 & 1.41 & -0.34 & 0.37 \\
\hline Cutpoint 5 & 6.63 & 5.25 & 2.89 & 3.80 & 2.61 & 2.78 & 1.49 & -0.14 & 0.53 \\
\hline Cutpoint 6 & 6.75 & 5.39 & 2.95 & 3.83 & 2.69 & 2.81 & 1.52 & -0.01 & 0.70 \\
\hline Cutpoint 7 & 6.79 & 5.42 & 2.98 & 3.89 & 2.74 & 2.83 & 1.55 & 0.11 & 0.81 \\
\hline Cutpoint 8 & 6.87 & 5.45 & 3.01 & 3.97 & 2.77 & 2.88 & 1.60 & 0.21 & 0.84 \\
\hline Cutpoint 9 & 7.03 & 5.59 & 3.06 & 4.00 & 2.87 & 2.96 & 1.63 & 0.29 & 0.87 \\
\hline Cutpoint 10 & 7.08 & 5.69 & 3.12 & 4.05 & 2.92 & 2.98 & 1.68 & 0.31 & 0.93 \\
\hline Cutpoint 11 & 7.16 & 5.76 & 3.20 & 4.08 & 2.95 & 3.01 & 1.70 & 0.38 & 0.98 \\
\hline Cutpoint 12 & 7.37 & 5.80 & 3.32 & 4.13 & 2.98 & 3.03 & 1.75 & 0.41 & 1.06 \\
\hline Cutpoint 13 & 7.51 & 5.90 & 3.38 & 4.22 & 3.00 & 3.08 & 1.80 & 0.57 & 1.15 \\
\hline Cutpoint 14 & 7.60 & 6.01 & 3.44 & 4.25 & 3.06 & 3.13 & 1.95 & 0.79 & 1.37 \\
\hline Cutpoint 15 & 7.78 & 6.12 & 3.50 & 4.28 & 3.08 & 3.18 & 2.08 & 0.99 & 1.69 \\
\hline Cutpoint 16 & 7.96 & 6.27 & 3.53 & 4.50 & 3.17 & 3.29 & 2.13 & 1.23 & 2.00 \\
\hline Cutpoint 17 & 8.01 & 6.44 & 3.59 & 4.68 & 3.23 & 3.46 & 2.38 & 1.56 & 2.29 \\
\hline Cutpoint 18 & --- & 6.48 & 3.80 & --- & 3.41 & 3.66 & 2.59 & --- & --- \\
\hline Cutpoint 19 & -- & -- & 4.00 & -- & 3.65 & -- & -- & -- & --- \\
\hline Number of obs & 76 & 90 & 97 & 103 & 104 & 105 & 105 & 117 & 115 \\
\hline Pseudo R-squared & 0.05 & 0.05 & 0.03 & 0.02 & 0.02 & 0.02 & 0.03 & 0.02 & 0.04 \\
\hline
\end{tabular}

NOTES: Dependent variable is the Polity score as described in text. Openness Residuals are the resdiuals of a regression of actual openness on predicted openness, population and land area. Heteroscedasticity consistent errors are reported in parentheses.

\begin{tabular}{l|cccccc}
\hline \hline & \multicolumn{7}{|c}{ Interwar Sample: 1920-1938 } \\
Variable & 1920 & 1925 & 1928 & 1932 & 1935 & 1938 \\
\hline Openness & 0.15 & 0.43 & 0.27 & 0.42 & 0.32 & 0.12 \\
& $(0.06)$ & $(0.12)$ & $(0.09)$ & $(0.23)$ & $(0.13)$ & $(0.05)$ \\
Openness Residuals & -0.11 & -0.31 & -0.16 & -0.33 & -0.23 & 0 \\
& $(0.06)$ & $(0.13)$ & $(0.11)$ & $(0.26)$ & $(0.16)$ & $(0.05)$ \\
In (Population) & 0.75 & 2.12 & 0.85 & 1.38 & 1.53 & 0.35 \\
& $(0.46)$ & $(0.87)$ & $(0.64)$ & $(1.22)$ & $(0.86)$ & $(0.49)$ \\
In (land area) & -0.28 & 0.06 & 0.2 & -0.02 & 0.13 & 0.18 \\
& $(0.21)$ & $(0.21)$ & $(0.22)$ & $(0.16)$ & $(0.14)$ & $(0.14)$ \\
& & & & & & \\
Cutpoint 1 & 10.59 & 43.16 & 19.53 & 26.92 & 30.48 & 7.56 \\
Cutpoint 2 & 11.43 & 43.81 & 20.25 & 27.28 & 31.53 & 8.46 \\
Cutpoint 3 & 11.72 & 44.02 & 20.49 & 27.52 & 31.66 & 8.63 \\
Cutpoint 4 & 11.98 & 44.26 & 21.07 & 28.01 & 31.90 & 8.93 \\
Cutpoint 5 & 12.51 & 44.51 & 21.26 & 28.15 & 32.14 & 9.31 \\
Cutpoint 6 & 12.81 & 44.80 & 21.47 & 28.41 & 32.26 & 9.44 \\
Cutpoint 7 & 13.31 & 45.06 & 21.72 & 28.55 & 32.38 & 9.58 \\
Cutpoint 8 & 13.86 & 45.30 & 21.96 & 28.69 & 32.52 & 9.73 \\
Cutpoint 9 & --- & 45.58 & 22.15 & 28.83 & 32.66 & 9.87 \\
Cutpoint 10 & --- & 46.09 & 22.34 & 28.95 & 32.94 & 10.01 \\
Cutpoint 11 & --- & --- & 22.53 & 29.21 & 33.12 & 10.16 \\
Cutpoint 12 & --- & --- & 22.90 & 29.34 & --- & 10.32 \\
\hline Number of obs & 22 & 26 & 27 & 29 & 29 & 29 \\
Pseudo R-squared & 0.22 & 0.29 & 0.22 & 0.12 & 0.16 & 0.14 \\
\hline \hline NOTES: Depend
\end{tabular}

NOTES: Dependent variable is the Polity score as described in text. Openness

Residuals are the resdiuals of a regression of actual openness on predicted

openness, population and land area. Heteroscedasticity consistent errors are reported in parentheses. 
Table 12: Ordered Probit "Instrumental Variables" Regressions with Additional Controls, 18701910

\begin{tabular}{|c|c|c|c|c|c|c|c|c|c|}
\hline \multirow[b]{2}{*}{ Variable } & \multicolumn{9}{|c|}{ Pre World War I Sample: 1870-1910 } \\
\hline & 1870 & 1875 & 1880 & 1885 & 1890 & 1895 & 1900 & 1905 & 1910 \\
\hline \multirow[t]{2}{*}{ Openness } & 0.06 & 0.04 & 0.02 & 0.001 & 0.02 & 0.06 & 0.01 & 0.01 & 0.05 \\
\hline & $(0.02)$ & $(0.02)$ & $(0.02)$ & $(0.03)$ & $(0.03)$ & $(0.04)$ & $(0.03)$ & $(0.02)$ & $(0.02)$ \\
\hline \multirow[t]{2}{*}{ Openness Residuals } & -0.04 & -0.02 & -0.01 & 0.004 & -0.01 & -0.06 & -0.02 & -0.01 & -0.05 \\
\hline & $(0.01)$ & $(0.02)$ & $(0.02)$ & $(0.03)$ & $(0.03)$ & $(0.04)$ & $(0.03)$ & $(0.02)$ & $(0.02)$ \\
\hline \multirow[t]{2}{*}{ In (Population) } & 0.67 & 0.34 & 0.14 & -0.17 & 0.04 & 0.53 & -0.1 & -0.31 & 0.1 \\
\hline & $(0.43)$ & $(0.48)$ & $(0.47)$ & $(0.62)$ & $(0.69)$ & $(0.63)$ & $(0.53)$ & $(0.43)$ & $(0.47)$ \\
\hline \multirow[t]{2}{*}{ In (land area) } & 0.17 & 0.12 & -0.16 & -0.21 & 0.1 & 0.35 & -0.003 & 0.1 & 0.52 \\
\hline & $(0.23)$ & $(0.33)$ & $(0.31)$ & $(0.34)$ & $(0.42)$ & $(0.42)$ & $(0.38)$ & $(0.32)$ & $(0.29)$ \\
\hline Cutpoint 1 & 14.31 & 7.09 & -0.89 & -7.55 & 1.08 & 13.95 & -2.96 & -5.33 & 8.66 \\
\hline Cutpoint 2 & 15.05 & 7.51 & -0.42 & -7.08 & 2.11 & 14.33 & -2.53 & -4.97 & 9.02 \\
\hline Cutpoint 3 & 15.30 & 7.81 & -0.11 & -6.79 & 2.41 & 15.13 & -2.05 & -4.51 & 9.27 \\
\hline Cutpoint 4 & 15.53 & 8.80 & 0.81 & -6.06 & 2.66 & 15.42 & -1.60 & -4.20 & 9.46 \\
\hline Cutpoint 5 & 16.16 & 9.10 & 1.08 & -5.80 & 3.02 & 15.67 & -1.47 & -4.07 & 9.63 \\
\hline Cutpoint 6 & 16.56 & 9.24 & 1.21 & -5.68 & 3.28 & 16.02 & -1.36 & -3.94 & 9.80 \\
\hline Cutpoint 7 & 16.74 & 9.39 & 1.34 & -5.45 & 3.41 & 16.15 & -1.01 & -3.58 & 10.24 \\
\hline Cutpoint 8 & 16.95 & 9.55 & 1.62 & -5.33 & 3.72 & 16.30 & -0.89 & -3.46 & 10.38 \\
\hline Cutpoint 9 & 17.16 & 9.73 & 1.78 & -5.07 & 3.91 & 16.44 & -0.64 & -3.35 & 10.51 \\
\hline Cutpoint 10 & 17.37 & 9.92 & 2.12 & -4.92 & --- & 16.76 & -0.51 & -3.12 & 10.77 \\
\hline Cutpoint 11 & 17.58 & 10.13 & --- & -4.57 & --- & 16.96 & -0.36 & -2.86 & 11.00 \\
\hline Cutpoint 12 & 17.85 & 10.36 & --- & --- & --- & --- & -0.19 & -2.71 & 11.26 \\
\hline Cutpoint 13 & 18.46 & --- & -- & --- & --- & --- & -- & -- & 11.41 \\
\hline Number of obs & 18 & 19 & 20 & 21 & 21 & 22 & 22 & 23 & 24 \\
\hline Pseudo R-squared & 0.1 & 0.05 & 0.03 & 0.02 & 0.01 & 0.03 & 0.02 & 0.02 & 0.05 \\
\hline
\end{tabular}

NOTES: Dependent variable is the Polity score as described in text. Openness Residuals are the resdiuals of a regression of actual openness on predicted openness, population and land area. Heteroscedasticity consistent errors are reported in parentheses. 
Table 13: Openness and the Components of Democracy, 1960-2000

\begin{tabular}{|c|c|c|c|c|c|c|c|c|c|}
\hline & 1960 & 1965 & 1970 & 1975 & 1980 & 1985 & 1990 & 1995 & 2000 \\
\hline \multicolumn{10}{|c|}{ Dependent variable: Competitiveness and openness of executive recruitment } \\
\hline Openness & $\begin{array}{l}0.1406 \\
(0.0387)\end{array}$ & $\begin{array}{l}0.1067 \\
(0.0373)\end{array}$ & $\begin{array}{l}0.0646 \\
(0.0378)\end{array}$ & $\begin{array}{l}0.0575 \\
(0.0246)\end{array}$ & $\begin{array}{l}0.0280 \\
(0.0138)\end{array}$ & $\begin{array}{l}0.0351 \\
(0.0208)\end{array}$ & $\begin{array}{l}0.0164 \\
(0.0147)\end{array}$ & $\begin{array}{l}0.0064 \\
(0.0126)\end{array}$ & $\begin{array}{l}0.0098 \\
(0.0106)\end{array}$ \\
\hline $\ln$ (population) & $\begin{array}{l}0.5978 \\
(0.2199)\end{array}$ & $\begin{array}{l}0.8059 \\
(0.2111)\end{array}$ & $\begin{array}{l}0.4428 \\
(0.2166)\end{array}$ & $\begin{array}{l}0.4478 \\
(0.2328)\end{array}$ & $\begin{array}{l}0.3485 \\
(0.2067)\end{array}$ & $\begin{array}{l}0.2436 \\
(0.1933)\end{array}$ & $\begin{array}{l}0.3358 \\
(0.1798)\end{array}$ & $\begin{array}{l}0.0786 \\
(0.1515)\end{array}$ & $\begin{array}{l}0.2175 \\
(0.1540)\end{array}$ \\
\hline $\ln$ (land area) & $\begin{array}{l}0.1682 \\
(0.2370)\end{array}$ & $\begin{array}{l}-0.2900 \\
(0.1755)\end{array}$ & $\begin{array}{l}-0.2138 \\
(0.1819)\end{array}$ & $\begin{array}{l}-0.0007 \\
(0.2232)\end{array}$ & $\begin{array}{l}-0.1371 \\
(0.2123)\end{array}$ & $\begin{array}{l}-0.1485 \\
(0.1858)\end{array}$ & $\begin{array}{l}-0.3533 \\
(0.1814)\end{array}$ & $\begin{array}{l}-0.1765 \\
(0.1625)\end{array}$ & $\begin{array}{l}-0.1174 \\
(0.1456)\end{array}$ \\
\hline Constant & $\begin{array}{l}-12.9336 \\
(4.5739)\end{array}$ & $\begin{array}{l}-10.2951 \\
(4.0740)\end{array}$ & $\begin{array}{l}-5.0369 \\
(3.7981)\end{array}$ & $\begin{array}{l}-8.4278 \\
(3.9254)\end{array}$ & $\begin{array}{l}-4.3296 \\
(2.8781)\end{array}$ & $\begin{array}{l}-2.1922 \\
(2.6423)\end{array}$ & $\begin{array}{l}-0.3859 \\
(2.3857)\end{array}$ & $\begin{array}{l}2.4562 \\
(2.3332)\end{array}$ & $\begin{array}{l}-0.6153 \\
(2.0632)\end{array}$ \\
\hline Observations & 74 & 87 & 97 & 101 & 99 & 103 & 103 & 113 & 114 \\
\hline R-squared & 0.1611 & 0.1748 & 0.1400 & --- & 0.0515 & 0.0403 & 0.1091 & 0.0516 & 0.0797 \\
\hline \multicolumn{10}{|c|}{ Dependent variable: Constraint on chief executive } \\
\hline Openness & $\begin{array}{l}0.1994 \\
(0.0390)\end{array}$ & $\begin{array}{l}0.1789 \\
(0.0409)\end{array}$ & $\begin{array}{l}0.0996 \\
(0.0656)\end{array}$ & $\begin{array}{l}0.0791 \\
(0.0363)\end{array}$ & $\begin{array}{l}0.0386 \\
(0.0202)\end{array}$ & $\begin{array}{l}0.0599 \\
(0.0362)\end{array}$ & $\begin{array}{l}0.0370 \\
(0.0237)\end{array}$ & $\begin{array}{l}0.0256 \\
(0.0216)\end{array}$ & $\begin{array}{l}0.0190 \\
(0.0139)\end{array}$ \\
\hline $\ln$ (population) & $\begin{array}{l}0.7867 \\
(0.2718)\end{array}$ & $\begin{array}{l}1.1057 \\
(0.2506)\end{array}$ & $\begin{array}{l}0.4895 \\
(0.3340)\end{array}$ & $\begin{array}{l}0.4911 \\
(0.3402)\end{array}$ & $\begin{array}{l}0.3943 \\
(0.2953)\end{array}$ & $\begin{array}{l}0.3513 \\
(0.2863)\end{array}$ & $\begin{array}{l}0.3768 \\
(0.2740)\end{array}$ & $\begin{array}{l}0.0903 \\
(0.2330)\end{array}$ & $\begin{array}{l}0.1397 \\
(0.2386)\end{array}$ \\
\hline $\ln$ (land area) & $\begin{array}{l}0.2195 \\
(0.2918)\end{array}$ & $\begin{array}{l}-0.2533 \\
(0.1914)\end{array}$ & $\begin{array}{l}-0.1248 \\
(0.2286)\end{array}$ & $\begin{array}{l}0.0198 \\
(0.3136)\end{array}$ & $\begin{array}{l}-0.0967 \\
(0.3095)\end{array}$ & $\begin{array}{l}0.0161 \\
(0.2631)\end{array}$ & $\begin{array}{l}-0.1213 \\
(0.2857)\end{array}$ & $\begin{array}{l}0.0463 \\
(0.2395)\end{array}$ & $\begin{array}{l}0.0242 \\
(0.2293)\end{array}$ \\
\hline Constant & $\begin{array}{l}-17.5783 \\
(4.6815)\end{array}$ & $\begin{array}{l}-16.9293 \\
(4.3520)\end{array}$ & $\begin{array}{l}-7.8776 \\
(5.6263)\end{array}$ & $\begin{array}{l}-10.2602 \\
(5.0665)\end{array}$ & $\begin{array}{l}-6.2591 \\
(3.7193)\end{array}$ & $\begin{array}{l}-6.7708 \\
(3.7718)\end{array}$ & $\begin{array}{l}-4.4676 \\
(3.5722)\end{array}$ & $\begin{array}{l}-0.9355 \\
(3.5140)\end{array}$ & $\begin{array}{l}-1.0988 \\
(2.9962)\end{array}$ \\
\hline Observations & 74 & 87 & 97 & 101 & 99 & 103 & 103 & 113 & 114 \\
\hline R-squared & 0.1788 & 0.2008 & 0.1281 & --- & 0.0366 & 0.0412 & 0.0631 & 0.0122 & 0.0811 \\
\hline \multicolumn{10}{|c|}{ Dependent variable: Competitiveness and regulation of political participation } \\
\hline Openness & $\begin{array}{l}0.1810 \\
(0.0414)\end{array}$ & $\begin{array}{l}0.1782 \\
(0.0468)\end{array}$ & $\begin{array}{l}0.0695 \\
(0.0623)\end{array}$ & $\begin{array}{l}0.0877 \\
(0.0383)\end{array}$ & $\begin{array}{l}0.0516 \\
(0.0230)\end{array}$ & $\begin{array}{l}0.0615 \\
(0.0394)\end{array}$ & $\begin{array}{l}0.0436 \\
(0.0240)\end{array}$ & $\begin{array}{l}0.0271 \\
(0.0206)\end{array}$ & $\begin{array}{l}0.0247 \\
(0.0116)\end{array}$ \\
\hline $\ln$ (population) & $\begin{array}{l}0.7151 \\
(0.2697)\end{array}$ & $\begin{array}{l}1.0930 \\
(0.2670)\end{array}$ & $\begin{array}{l}0.4702 \\
(0.3272)\end{array}$ & $\begin{array}{l}0.5544 \\
(0.3667)\end{array}$ & $\begin{array}{l}0.4251 \\
(0.3297)\end{array}$ & $\begin{array}{l}0.3047 \\
(0.3018)\end{array}$ & $\begin{array}{l}0.3078 \\
(0.2895)\end{array}$ & $\begin{array}{l}-0.0191 \\
(0.2389)\end{array}$ & $\begin{array}{l}-0.0619 \\
(0.2381)\end{array}$ \\
\hline $\ln$ (land area) & $\begin{array}{l}0.1790 \\
(0.3443)\end{array}$ & $\begin{array}{l}-0.3734 \\
(0.2146)\end{array}$ & $\begin{array}{l}-0.2969 \\
(0.2489)\end{array}$ & $\begin{array}{l}0.0089 \\
(0.3393)\end{array}$ & $\begin{array}{l}-0.0045 \\
(0.3410)\end{array}$ & $\begin{array}{l}-0.0111 \\
(0.2740)\end{array}$ & $\begin{array}{l}-0.0608 \\
(0.3053)\end{array}$ & $\begin{array}{l}0.1776 \\
(0.2259)\end{array}$ & $\begin{array}{l}0.1718 \\
(0.2102)\end{array}$ \\
\hline Constant & $\begin{array}{l}-16.9854 \\
(5.0138)\end{array}$ & $\begin{array}{l}-16.5186 \\
(4.6598)\end{array}$ & $\begin{array}{l}-6.0456 \\
(5.6167)\end{array}$ & $\begin{array}{l}-12.6961 \\
(5.1918)\end{array}$ & $\begin{array}{l}-9.6547 \\
(3.8864)\end{array}$ & $\begin{array}{l}-6.9149 \\
(3.9270)\end{array}$ & $\begin{array}{l}-5.4351 \\
(3.4039)\end{array}$ & $\begin{array}{l}-1.8097 \\
(3.2374)\end{array}$ & $\begin{array}{l}-0.6783 \\
(2.8069)\end{array}$ \\
\hline Observations & 74 & 87 & 97 & 101 & 99 & 103 & 103 & 113 & 114 \\
\hline R-squared & 0.1614 & 0.1286 & 0.1178 & --- & --- & 0.0307 & 0.0417 & --- & 0.0438 \\
\hline \multicolumn{10}{|c|}{ Dependent variable: Aggregate Polity Score (from Table 10) } \\
\hline Openness & $\begin{array}{l}0.5189 \\
(0.1104)\end{array}$ & $\begin{array}{l}0.4329 \\
(0.1084)\end{array}$ & $\begin{array}{l}0.2338 \\
(0.1612)\end{array}$ & $\begin{array}{l}0.2263 \\
(0.0969)\end{array}$ & $\begin{array}{l}0.1155 \\
(0.0540)\end{array}$ & $\begin{array}{l}0.1546 \\
(0.0928)\end{array}$ & $\begin{array}{l}0.0924 \\
(0.0601)\end{array}$ & $\begin{array}{l}0.0669 \\
(0.0498)\end{array}$ & $\begin{array}{l}0.0569 \\
(0.0321)\end{array}$ \\
\hline $\ln$ (population) & $\begin{array}{l}2.1643 \\
(0.7006)\end{array}$ & $\begin{array}{l}2.9141 \\
(0.6792)\end{array}$ & $\begin{array}{l}1.4025 \\
(0.8449)\end{array}$ & $\begin{array}{l}1.5147 \\
(0.9111)\end{array}$ & $\begin{array}{l}1.0818 \\
(0.7733)\end{array}$ & $\begin{array}{l}0.9029 \\
(0.7566)\end{array}$ & $\begin{array}{l}1.1505 \\
(0.6964)\end{array}$ & $\begin{array}{l}0.1990 \\
(0.6046)\end{array}$ & $\begin{array}{l}0.3047 \\
(0.5991)\end{array}$ \\
\hline $\ln$ (land area) & $\begin{array}{l}0.5403 \\
(0.8243)\end{array}$ & $\begin{array}{l}-0.9078 \\
(0.4920)\end{array}$ & $\begin{array}{l}-0.6355 \\
(0.6142)\end{array}$ & $\begin{array}{l}0.0102 \\
(0.8473)\end{array}$ & $\begin{array}{l}-0.2067 \\
(0.7888)\end{array}$ & $\begin{array}{l}-0.1564 \\
(0.6988)\end{array}$ & $\begin{array}{l}-0.6402 \\
(0.7339)\end{array}$ & $\begin{array}{l}0.0761 \\
(0.5427)\end{array}$ & $\begin{array}{l}0.1017 \\
(0.5439)\end{array}$ \\
\hline Constant & $\begin{array}{l}-48.0680 \\
(13.1334)\end{array}$ & $\begin{array}{l}-41.9400 \\
(11.8439)\end{array}$ & $\begin{array}{l}-18.9600 \\
(14.3517)\end{array}$ & $\begin{array}{l}-31.5138 \\
(13.4647)\end{array}$ & $\begin{array}{l}-19.0725 \\
(9.5113)\end{array}$ & $\begin{array}{l}-15.7134 \\
(9.8893)\end{array}$ & $\begin{array}{l}-11.0555 \\
(8.9135)\end{array}$ & $\begin{array}{l}-1.8247 \\
(7.8978)\end{array}$ & $\begin{array}{l}-2.9754 \\
(7.3093)\end{array}$ \\
\hline Observations & 76 & 90 & 97 & 103 & 104 & 105 & 105 & 117 & 115 \\
\hline R-squared & 0.1821 & 0.2105 & 0.1458 & -- & 0.0202 & 0.0393 & 0.0810 & 0.0229 & 0.0908 \\
\hline
\end{tabular}

Notes:

Figures reported come from a regression of each component of the polity score on openness.

Instrumental variable for openness is the value of predicted openness as described in the text.

Robust standard errors, clustered by country, are reported.

* significant at $10 \%$; ** significant at $5 \%$; *** significant at $1 \%$ 
Figure 1: Global Un-Weighted Averages of Democracy and Openness, 1870-1910

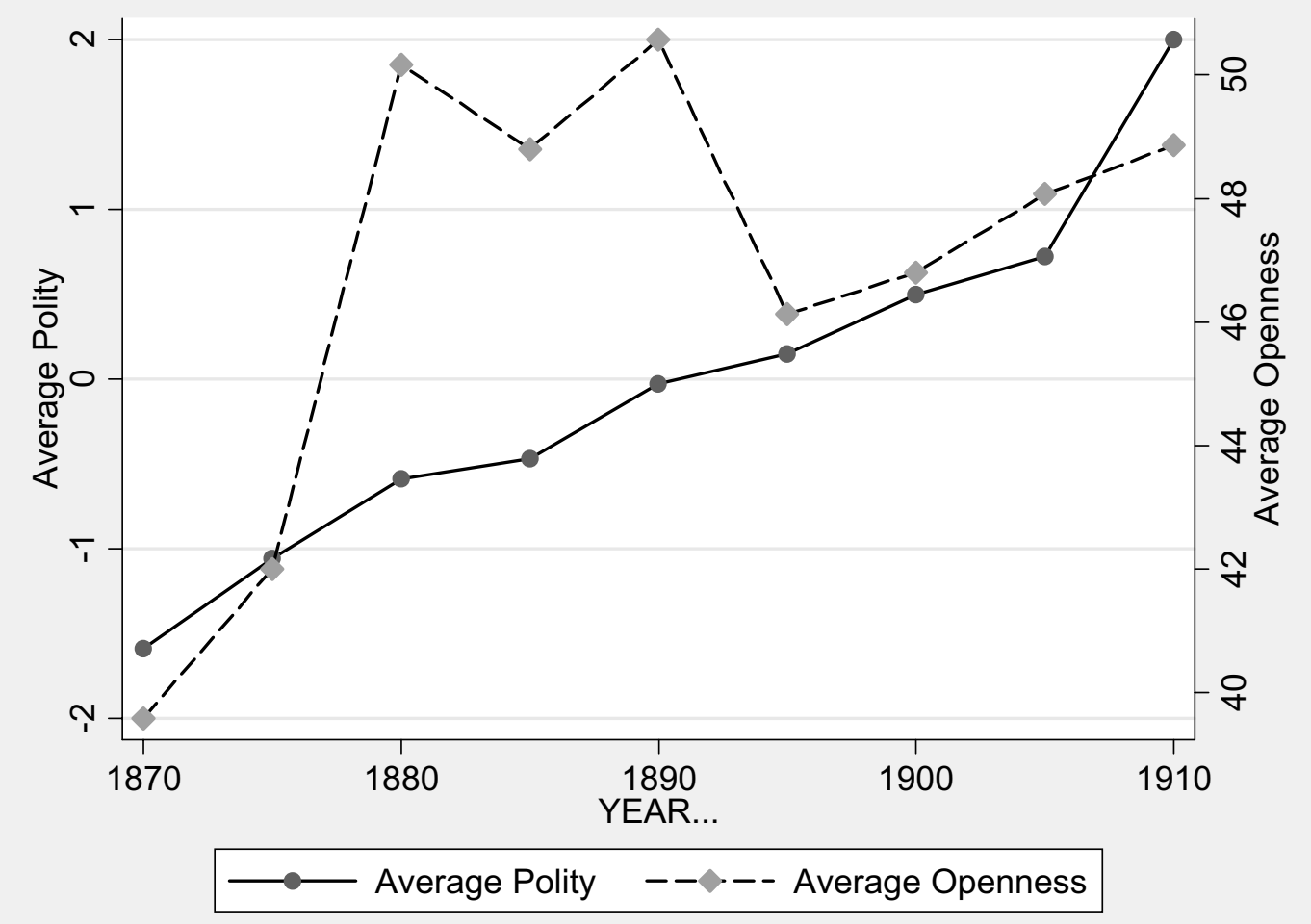


Figure 2: Global Un-Weighted Averages of Democracy and Openness, 1917-1939

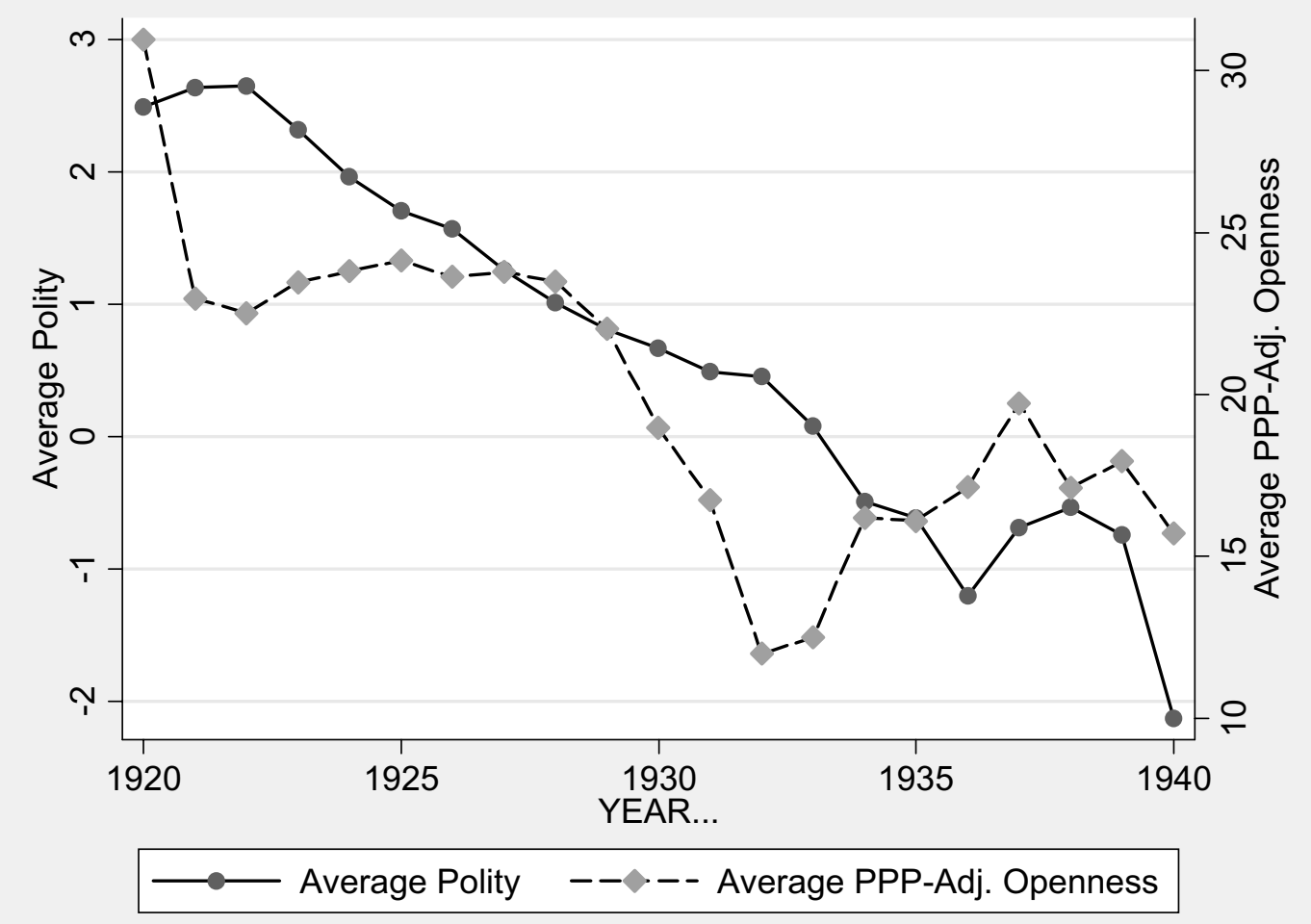


Figure 3: Global Averages of Democracy and Openness, 1960-2000

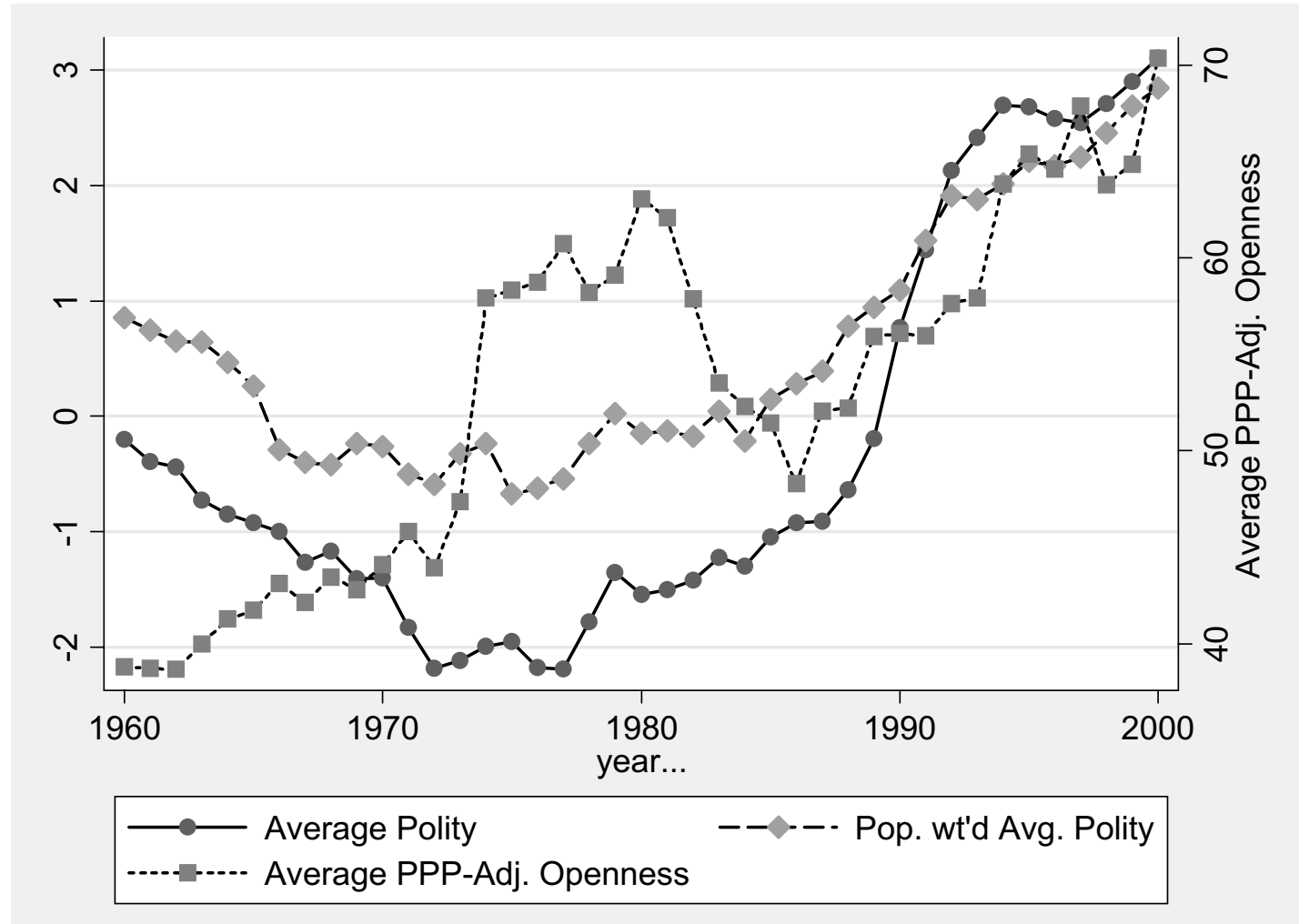

